\title{
U-PB AND HF ISOTOPIC ANALYSIS OF DETRITAL ZIRCONS FROM PALEOZOIC AND CRETACEOUS STRATA OF SOUTHERN VANCOUVER ISLAND, BRITISH COLUMBIA
}

by

Daniel G. Alberts

Copyright (C Daniel Alberts 2019

\author{
A Thesis Submitted to the Faculty of the \\ DEPARTMENT OF GEOSCIENCES \\ In Partial Fulfillment of the Requirements \\ For the Degree of \\ MASTER OF SCIENCE \\ In the Graduate College \\ THE UNIVERSITY OF ARIZONA
}

2019 


\section{THE UNIVERSITY OF ARIZONA GRADUATE COLLEGE}

As members of the Master's Committee, we certify that we have read the thesis prepared by Daniel G. Alberts, titled U-Pb and Hf Isotopic Analysis of Detrital Zircons from Paleozoic and Cretaceous Strata of Southern Vancouver Island, British Columbia and recommend that it be accepted as fulfilling the dissertation requirement for the Master's Degree.

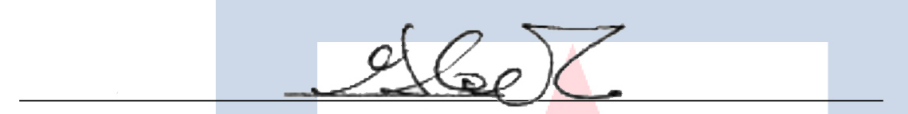

George Gehrels
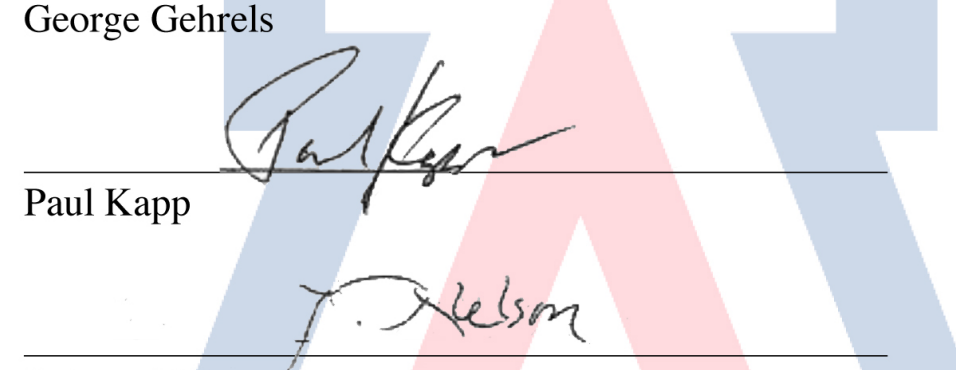

JoAnne Nelson

[Committee Member Name]
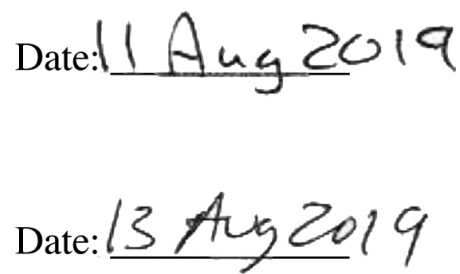

Date: Tuly 192019

Date:

Final approval and acceptance of this thesis is contingent upon the candidate's submission of the final copies of the thesis to the Graduate College.

I hereby certify that I have read this thesis prepared under my direction and recommend that it be accepted as fulfilling the Master's requirement.

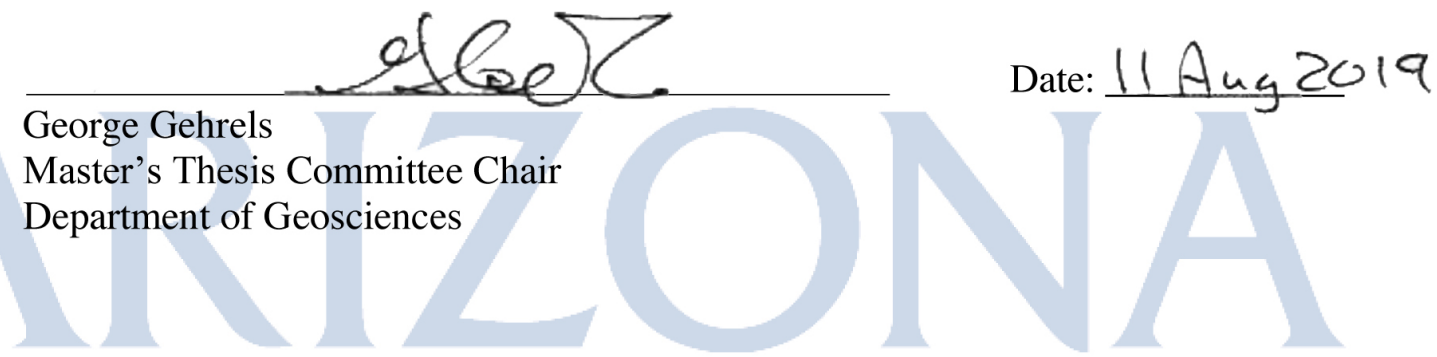




\section{Acknowledgements}

Field work for this project was supported by NSF EAR 1347375. Laboratory analyses were supported by NSF EAR 1649254 to the Arizona LaserChron Center. Additional thanks to Graham Nixon for comments and edits. We thank Rebecca Alberts for assistance in the field and Mark Pecha, Nicky Giesler, Chesi White, Kojo Plange, Clay Kelty, Gayland Simpson, and Ken Kanipe for assistance with the laboratory analyses. 


\section{Table of Contents}

Abstract..................................................................... 5

1. Introduction.......................................................... 6

2. Geology of Vancouver Island......................................7

3. Analytical Methods................................................ 14

4. U-Pb Geochronology and Hf Isotope Geochemical Results..............15

5. Provenance of the Fourth Lake Formation............................20

6. Provenance of the Comox Formation.................................... 22

7. Discussion.......................................................... 24

8. Tectonic Implications for Paleozoic Wrangellia....................... 26

9. Conclusion......................................................... 28

Figure Captions......................................................... 29

Figures....................................................................... 34

References Cited............................................................ 46 


\title{
$\mathrm{U}-\mathrm{Pb}$ and Hf isotopic analysis of detrital zircons from Paleozoic and Cretaceous strata of southern Vancouver Island, British Columbia
}

\author{
Daniel Alberts ${ }^{1}$, George E. Gehrels ${ }^{1}$, JoAnne Nelson ${ }^{2}$ \\ 1.Department of Geosciences, University of Arizona \\ Tucson, AZ USA 85721 \\ 2. British Columbia Geological Survey \\ Victoria, British Columbia V8W 9N3
}

\begin{abstract}
Wrangellia, an exotic arc terrane to North America, is interpreted to have been constructed near the margin of the Paleo-Arctic and Paleo-Pacific during middle-late Paleozoic time, before finally accreting to the western margin of North America during Late Jurassic to Early Cretaceous time. Utilizing the detrital zircon record of Paleozoic sedimentary rocks and Cretaceous basin fill we can provide further insight into the magmatic and depositional evolution of southern Wrangellia. 1422 U-Pb LA-ICPMS analyses from five samples of the Fourth Lake Formation in the Carboniferous Buttle Lake Group were performed. 1055 U-Pb LA-ICPMS analyses from four samples of the Comox formation within the Cretaceous Nanaimo Group were acquired in order to provide a broader sampling of the Lower Mesozoic-Paleozoic rocks of Vancouver Island.

$\mathrm{U}-\mathrm{Pb}$ analyses within the Fourth Lake Formation reveal prominent Carboniferous age peaks $(344,339,336,331$, and $317 \mathrm{Ma})$, with minor pre-400 Ma grains from adjacent terranes of Paleo-Arctic origin. Paleozoic detrital zircons exhibit juvenile, with $\mathrm{EHf}_{(\mathrm{t})}$ values between +15 and +5 . U-Pb analyses of Nanaimo Group sedimentary rocks reveal dominant peak ages at 341, 195, 167, and $86 \mathrm{Ma}$. All major populations yield juvenile epsilon $\mathrm{EHf}_{(\mathrm{t})}$ values in the range of +15 to +6 .

The detrital zircon $\mathrm{U}-\mathrm{Pb}$ geochronologic and $\mathrm{Hf}$ isotope data in this study suggest that sediment from the Fourth Lake Formation was derived mainly from bimodal magmatism within the Paleozoic southern Wrangellia arc system as well as minor
\end{abstract}


contributions of recycled detritus from the adjacent Alexander Terrane. Hf isotope data from the Comox Formation indicate that Triassic and Jurassic igneous rocks of the Bonanza Arc, and Late Jurassic-Early Cretaceous sources from the central Coast Mountains Batholith (CMB), are highly juvenile. This new geochronologic and geochemical data set contributes to a new tectonic model for the Paleozoic Southern Wrangellia Arc system from Late Devonian to Early Permian time and reveals, during Cretaceous time, very locally derived detritus was deposited in sedimentary basins along the inboard margin of Wrangellia.

\section{Introduction}

Wrangellia is a Devonian and younger arc terrane that extends over $\sim 2500 \mathrm{~km}$ from south-central Alaska (northern Wrangellia), southward to Haida Gwaii and Vancouver Island (southern Wrangellia) (Fig. 1). The oldest rocks of Wrangellia, preserved in the southern portion of the terrane consist of Upper Devonian to Lower Permian volcanic and sedimentary rocks of the Sicker and Buttle Lake Groups (Sutherland Brown et al., 1986; Juras, 1987, Massey, 1995a, b, c; Yorath et al., 1999). These units are overlain by basaltic rocks of the Triassic Karmutsen Formation, which initially defined the terrane (Jones et al., 1977; Greene et al., 2010). A younger, latest Triassic-Jurassic, arc is represented by stratified volcanic-sedimentary rocks of the Bonanza Group and the comagmatic Island Intrusions (Isachsen, 1987; Massey and Friday, 1988; Nixon et al., 1994; Debari et al., 1999; Paulson, 2010). Upper Cretaceous basin sediments of the Nanaimo Group were deposited on top of, and adjacent to, the older stratigraphic units of southern Wrangellia (Muller and Jeletzky, 1970; England, 1990; Mustard, 1994; Katnick and Mustard, 2003; Bain and Hubbard, 2016; Matthews et al., 2017).

Definition of the Paleozoic southern Wrangellia arc system is supported by stratigraphic studies of Paleozoic rocks on Vancouver Island along with well-constrained biostratigraphic and radiometric ages, and geochemical characterization (Brandon et al., 1986; Orchard, 1987; Matysek et al., 1990; Samson et al., 1990; Andrew et al., 1991; 
Massey, 1995a, b, c; Katvala and Henderson, 2002; Ruks, 2015). The system developed on juvenile oceanic crust that may have been contaminated by an older sediment source during the early stages of arc development (Samson et al., 1990; Massey, 1995a, b, c; Ruks, 2015). It has recently been recognized to contain two different pulses of bimodal arc magmatism, the oldest preserved in rocks of the Sicker Group and with the second pulse occurring coeval with deposition of sedimentary rocks of the Buttle Lake Group (Ruks, 2015).

This study presents $\mathrm{U}-\mathrm{Pb}$ ages and $\mathrm{Hf}$ isotope compositions of detrital zircons deposited during the arc building processes of southern Wrangellia from early Mississippian to Early Permian time, in order to further constrain southern Wrangellia's magmatic history. We analyzed nine samples from southern Vancouver Island, including five samples from the Paleozoic Fourth Lake Formation and four samples from the Comox Formation within the Upper Cretaceous Nanaimo Group (Figures. 1 and 2). Samples collected from the Nanaimo Group were analyzed primarily to gather additional information about the Paleozoic history of Vancouver Island by way of recycled zircons.

The following discussion of Vancouver Island stratigraphic and intrusive units focusses on them as potential sources for detrital zircons in clastic strata.

\section{Geology of Vancouver Island}

\subsection{Paleozoic rocks}

The oldest rocks on Vancouver Island record the evolution of the Paleozoic southern Wrangellia arc system, including Late Devonian arc rocks of the Sicker Group and Mississippian-Permian strata of the Buttle Lake Group (Figures 1 and 2). The Sicker Group includes the oldest rocks known to Wrangellia which mainly outcrops in the Buttle Lake and Cowichan Uplifts in central and southern Vancouver Island (Fig. 1) (Massey and Friday, 1988, 1989; Massey, 1995a, b, c; Ruks, 2015). These uplifts also expose sedimentary units of the overlying Buttle Lake Group and related igneous rocks (Fig. 1) (Massey, 1995a, b, c). 
Ruks (2015) performed an extensive geochronologic and geochemical study of Paleozoic igneous rocks from north-central to southern Vancouver Island (Fig. 1). Several igneous rocks and two detrital samples (from Upper Devonian to Lower Permian strata) were analyzed to further constrain ages and the magmatic evolution of Vancouver Island. Zircon U-Pb analyses from Ruks (2015) utilized LA-ICPMS and ID-TIMS age dating methods that produced $832 \mathrm{U}-\mathrm{Pb}$ ages from 44 samples (Fig. 4). U-Pb ages from Ruks (2015) are presented in sections 2.1.1 to 2.1.4 and Figure 4. Data tables with ages separated by geographic location for Ruks (2015) can be found in DR Table 1c.-1e.

\subsubsection{The Sicker Group}

Three distinct volcanic and volcaniclastic assemblages make up the Sicker Group, with predominantly island arc tholeiites (IAT) and light rare earth element enriched island arc tholeiite (L-IAT) chemistry (Massey, 1988; Ruks, 2015). The Duck Lake Formation is the lowermost stratigraphic unit. Chert samples collected at its base of the contain radiolarian assemblages of Middle to Late Devonian age, and a dacite flow interbedded with basalt flows yielded a U-Pb age of $366 \mathrm{Ma}$ (Ruks, 2015). A heterolithic lapilli tuff assigned to the Duck Lake yields an age of $351 \mathrm{Ma}$, indicating that the Duck Lake Formation has an age range from $\sim 366-351 \mathrm{Ma}$ (Ruks, 2015). Volcanogenic massive sulfide (VMS) deposits related to the Myra Falls Formation, outcropping in the Buttle Lake Uplift, yield ages from 370-361 Ma and are interpreted to correlate with volcanic rocks of the Duck Lake (Juras, 1987; Parrish and McNicoll, 1992; Ruks 2015) (Fig. 1). The Duck Lake Formation has previously been interpreted to represent the oceanic crust basement upon which the Paleozoic arc of Wrangellia was built (Massey, 1995a, b, c; Yorath, 1999), however the presence of abundant IAT and L-IAT igneous rocks and the lack of abundant N-MORB rocks suggests that the oceanic crust basement may not be exposed or has yet to be identified on Vancouver Island (Ruks, 2015).

The Nitinat Formation, which overlies the Duck Lake Formation, consists of mafic submarine volcanic and volcaniclastic rocks that most likely erupted from several volcanic centers (Fig. 2) (Massey, 1995a, b, c). Cross-cutting quartz-feldspar rhyolite 
porphyries in the Nitinat Formation yield an age of $360 \mathrm{Ma}$ (Ruks, 2015). A rhyolitic tuff near the contact of the Duck Lake and Nitinat Formations, in the Cowichan Uplift, yield ages ranging from 366-360 Ma (Ruks, 2015). The Nitinat represents early stages of arc development, interpreted to be similar to modern young submarine arcs (Massey, 1995a, $b, c)$.

The youngest rocks within the Sicker Group are assigned to the McLaughlin Ridge Formation. Deposition of volcaniclastic rocks and related intrusive rocks were sourced from a single large volcanic center with ages ranging from 363-353 Ma (Ruks, 2015). The McLaughlin Ridge Formation represents a partially subaerial, mature arc (Fig. 2) (Massey, 1995a, b, c).

Granodiorite stocks and quartz porphyry dikes of the Saltspring intrusion are coeval with the felsic magmatisim of the McLaughlin Ridge Formation, they also intrude the Nititnat Formation (Massey, 1995c; Ruks, 2015). They outcrop in southeastern Vancouver Island, specifically on Saltspring Island (Figures 1 and 2) (Massey, 1995c). The Saltspring intrusion yields similar ages as the McLaughlin Ridge Formation from 363-353 Ma (Brandon et al., 1986; Yorath et al., 1999; Sluggett, 2003; Ruks, 2015).

$\mathrm{Nd}$ isotope data for several felsic to mafic whole rock samples from ca. $360 \mathrm{Ma}$ rocks of the Sicker Group yield $\varepsilon N d_{(t)}$ values from +5.9 to +4.5 (Ruks, 2015). These values are interpreted to be geochemically juvenile to marginally intermediate, which contributes to previous evidence for a theorized sediment contribution that enriched magmas during early phases of arc construction (Samson et al., 1990; Massey, 1995a, b, c; Ruks, 2015). Data tables with Nd isotope data from Ruks (2015) can be found in DR Table $3 \mathrm{~d}$ and in Figure 5.

Middle-Late Devonian to Early Mississippian rocks of the Sicker Group are referred to herein as the Sicker arc, which represents an early phase of magmatism in the Paleozoic southern Wrangellia arc system. Concluding Sicker Arc magmatism, a slab 
rollback event in Early Mississippian time is interpreted by Ruks (2015) to have partially rifted the pre-existing arc and formed a back-arc basin (Ruks, 2015).

\subsubsection{The Buttle Lake Group}

Rocks of the Buttle Lake Group consist of chert, bedded epiclastic strata and bioclastic limestone that depositionally overlie the Nitinat and McLaughlin Ridge Formations (Figures 1 and 2). The Fourth Lake Formation, the oldest unit within the Buttle Lake Group, is the target unit for this study (Fig. 2). The lower Fourth Lake Formation consist of a 100-200-meter-thick sequence of radiolarian ribbon chert, whereas strata overlying the Fourth Lake Formation consists of cherty siltstones, thin siltstoneargillite beds, and thinly bedded fine to medium grained turbiditic sandstones (Fig. 3, pictures A, B, E, F, and G). Previous detrital zircon dating of the Fourth Lake Formation yielded ages ranging from 355-294 Ma [samples 08TR017 and 08TR019 from Ruks, (2015)] (Figures 1 and 4), with dominant peak ages of 320, 312, and $304 \mathrm{Ma}$ (Ruks, 2015). The Fourth Lake Formation is interpreted to represent a marginal-basin assemblage that developed with coeval VMS type deposits in the back-arc of southern Wrangellia and buried rocks of the Sicker arc (Massey, 1995; Ruks, 2015).

The Mount Mark Formation, which overlies the Fourth Lake Formation, is a massive limestone unit rich in marine fossils commonly found in cool shallow water (Webster et al., 2009) (Fig. 2). Sedimentary rocks in the Buttle Lake Uplift assigned to the Thelwood Formation are interpreted to correlate with the Fourth Lake and Mount Mark Formations (Ruks, 2015). Conformably overlying the Mount Mark Formation, is a sequence of clastic and volcaniclastic rocks of the St Mary's Lake Formation (Fig. 2) (Massey, 1988; Massey, 1995c). The St. Mary's Lake Formation is interpreted to be Early Permian in age in that it overlies Early Permian cherts, however no radiometric or faunal ages have been obtained from it.

\subsubsection{Bimodal volcanism associated with the Buttle Lake Group}

A pulse of bimodal volcanism from Mississippian to Early Permian time is observed in the Buttle Lake Group (Ruks, 2015). Tuffaceous, felsic intrusive, and VMS 
porphyry rocks related to this second pulse of bimodal volcanism outcrop in the Cowichan and Bedingfield uplifts and on the Dragon property near the Buttle Lake Uplift (Fig. 1).

Felsic volcanic and tuffaceous rocks in the Cowichan uplift range in age from 347$335 \mathrm{Ma}$, and rhyolite porphyry bodies yield ages from 338-335 Ma (Ruks, 2015) (Fig. 1). A heterolithic lapilli tuff from the northern portion of the Cowichan Uplift yields three distinct populations with age ranges of 339-337 Ma, 322-309 Ma, and ca. $295 \mathrm{Ma}$, which represents the age of the tuff (Ruks, 2015). The two older populations are interpreted to have been extruded from a volcanic center constructed on top of Mississippian to Pennsylvanian igneous rocks (Ruks, 2015). This interpretation is significant considering that there are no igneous rocks recognized on Vancouver Island with ages ranging from 334-314 Ma, which is described as a "magmatic gap" in the arc system of southern Wrangellia (Ruks, 2015). Zircon with ages in this magmatic gap are also observed in two detrital samples reported by Ruks (2015) (Fig. 4).

Felsic volcanic rocks associated with VMS deposits in the Bedingfield uplift yield ages of 312, 308, and $305 \mathrm{Ma}$ (Ruks, 2015) (Fig. 1). Similar VMS associated felsic rocks in the Dragon property yield U-Pb zircon ages from 311-300 Ma and are overlain by felsic tuffs with ages of 293 and $291 \mathrm{Ma}$ (Ruks, 2015) (Fig. 1). Nd isotope data for igneous rocks representing the second pulse of bimodal arc magmatism yield values ranging from +7.0 to +4.3 at an age of ca. $300 \mathrm{Ma}$ and a single value with a corresponding age of ca. 317 Ma yields a $\varepsilon \mathrm{Nd}_{(\mathrm{t})}$ value of +6.1 (Ruks, 2015). These values are marginally more juvenile than rocks of the Sicker Group.

\subsubsection{Arc migration in the Paleozoic southern Wrangellia arc system}

An apparent northward arc migration is revealed through correlations between U$\mathrm{Pb}$ ages and the geographic location of igneous samples from Ruks (2015). 32 samples and $565 \mathrm{U}-\mathrm{Pb}$ ages from the Cowichan uplift are primarily igneous rocks of the Sicker Group (Fig. 1), and yield an age range of 372-289 Ma, with a corresponding peak age of 
$358 \mathrm{Ma}$ (Fig. 4). 11 samples and $180 \mathrm{U}-\mathrm{Pb}$ ages from samples collected from the Bedingfield uplift and Dragon property are igneous rocks related to the Buttle Lake Group (Fig. 1), and yield a predominant age range of 325-274 Ma with a corresponding peak age of $305 \mathrm{Ma}$ (Fig. 4). Overlap in ages occur from 340-320 Ma interval, indicating the primary time of arc migration (Fig. 4).

\subsection{Mesozoic rocks}

\subsubsection{The Karmutsen Formation}

Paleozoic rocks on Vancouver Island are overlain unconformably by the Karmutsen flood basalts, which draped a minimum of $3.5 \mathrm{~km}$ of submarine flows and pillow basalts on to Paleozoic rocks from 230-225 Ma (Parrish and McNicoll, 1992; Lasiter, 1995; Greene et al., 2010) (Figures 1 and 3). Gabbroic rocks related to Karmutsen basalts have yielded U-Pb zircon ages of $228 \mathrm{Ma}$ and $226 \mathrm{Ma}$ from outcrops on Saltspring Island in southern Vancouver Island (Sluggett, 2003).

\subsubsection{The Bonanza Group}

The youngest arc related Wrangellian strata on Vancouver Island belong to uppermost Triassic-Jurassic Bonanza Group (Figures 1 and 2). Present exposures, allow observations of the Bonanza arc at different depths within the crust: the upper portion includes the Bonanza Group and the Island Intrusions, whereas the West Coast Crystalline Complex (WCC) represents the lower portion of the arc (Isachsen, 1987; Nixon et al., 1994; Debari et al., 1999; Paulson, 2010). The West Coast Crystalline Complex contains gabbroic to dioritic plutonic rocks, migmatites, amphibolites, and metasedimentary rocks, and preserves the deepest section of the Bonanza arc, while the mid-crustal section is preserved in batholiths and felsic intrusions of the Island Intrusive Suite (Debari et al. 1999; Paulson, 2010) (Fig. 1). The Bonanza Group represents arc volcanism comprising $\sim 2,500$ meters of lava flows, pyroclastic flows, thin interbedded sedimentary units, and minor low-grade metamorphic rock that have been intruded by the Island Intrusions (Muller, 1974; Nixon et al., 1994; Nixon and Orr, 2006; Paulson, 2010; 
Nixon et al., 2011) (Fig. 1). The WCC yields various U-Pb zircon ages ranging from 190$177 \mathrm{Ma}$ (Isachsen, 1987; DeBari et al., 1999), a Rb-Sr age of $151 \mathrm{Ma}$ (Isachsen, 1987), and K-Ar ages of 172 and $163 \mathrm{Ma}$ (Wanless et al, 1974; Isachsen, 1987). The Island Intrusions yield U-Pb zircon crystallization ages from $175-168 \mathrm{Ma},{ }^{40} \mathrm{Ar}-{ }^{39} \mathrm{Ar}$ cooling ages of 176 and $166 \mathrm{Ma}$, and a K-Ar age range of 181-152 Ma (Carson, 1973; Muller, 1977), whereas the Bonanza Group yields a U-Pb zircon crystallization age range from 202-165 Ma (Friedman and Nixon, 1995; Debari et al., 1999).

Whole rock geochemical data from volcanic rocks of the Bonanza Group indicate that melts were primarily mantle derived with varying amounts of sediment components from country rock on Vancouver Island (i.e. the Sicker Group, Buttle Lake Group, and Karmutsen flood basalts), which contributes to a moderately intermediate to juvenile geochemical signature (Paulson, 2010). This Jurassic arc sequence is associated with the Talkeetna-Bonanza Arc system that extends northward into southern Alaska (Clift et al., 2005; Paulson et al., 2010; Canil et al., 2012).

\subsubsection{The Nanaimo Group}

The Upper Cretaceous Nanaimo Group consists of a $\sim 5 \mathrm{~km}$ thick sequence of nonmarine to deep-marine basin strata that rest unconformably on Paleozoic and Jurassic strata of southern Wrangellia (Figures 1 and 2) (England, 1990; Mustard, 1994; Katnick and Mustard, 2003; Bain and Hubbard, 2016; Matthews et al., 2017). The Comox Formation, the basal unit of the Nanaimo Group contains various macrofossil assemblages that indicate a depositional age from Turonian to Coniacian time (Haggart, 1991, 1994; Haggart et al., 2005; Johnstone et al., 2005). A varying thickness of 0-350 m is reported for the Comox Formation, which consists primarily of poorly bedded cobble to boulder conglomerates. Clasts are angular to rounded with clast compositions derived from older strata on Vancouver Island (Figure 3 pictures C and D). The Comox Formation is interpreted to consist, in some areas, of fluvial sediments that were trapped by topographic highs during deposition, whereas in other areas consists of deltaic deposits (Johnstone et al., 2006). 
A study conducted by Matthews et al. (2017) has provided a robust detrital zircon $\mathrm{U}-\mathrm{Pb}$ data set for several units within the Nanaimo Group. Two samples from the Comox Formation ( $\mathrm{CO} 1$ and $\mathrm{CO} 2)$ from the east-central coast of Vancouver Island (Fig. 1) yield similar age ranges with corresponding peak ages of $154 \mathrm{Ma}$ and $153 \mathrm{Ma}$, and $94 \mathrm{Ma}$ and $91 \mathrm{Ma}$, respectively (Fig. 6). Sample CO2 yields a third peak age of $167 \mathrm{Ma}$ that includes 50 grains with ages ranging from $204 \mathrm{Ma}$ to $163 \mathrm{Ma}$ (Fig. 6). A source from the central Coast Mountain Batholith is the preferred provenance interpretation made by Matthews et al. (2017) for zircon grains with ages from 150-80 Ma. This interpretation is consistent with previous studies indicating that Late Jurassic to mid-Cretaceous plutons of the Coast Mountains Batholith contributed significant sediment to the Nanaimo Group (Mustard, 1994; Mustard et al., 1995; Mahoney et al., 1999; Katnick and Mustard, 2003). Matthews et al. (2017) proposed a provenance for grains $>160$ Ma to be derived from the MojaveSonoran region. However, the ca. 204-163 Ma grains in sample CO2 are consistant with sources in the Bonanza Group/Island Intrusions and plutons in the southwestern Coast Mountains. Data tables with the ages from the Comox Formation from Matthews et al. (2017) can be found in DR Table 1f.

\section{Analytical Methods}

Zircon separation was performed at the Arizona LaserChron Center (www.laserchron.org) using methods described by Gehrels et al. (2008), Gehrels and Pecha (2014), and Pullen et al. (2018), including crushing/pulverizing, followed by separation with a Wifley table, Frantz magnetic separator, and heavy liquids (MI). Grains from each sample were poured in a 1" epoxy mount alongside fragments of $\mathrm{U}-\mathrm{Pb}$ zircon standards (FC-1, SL2, and R33) and Hf zircon standards (Mud Tank, Temora-2, FC-1, 91500, Plesovice, R33, and SL2). Mounts were polished with a series of different grit sand papers and finished with a $1 \mathrm{um}$ diamond polish. All sample mounts were imaged using cathodoluminesence (CL) and backscatter electron (BSE) methods. Samples were cleaned with a $2 \% \mathrm{HNO}_{3}$ and $1 \% \mathrm{HCL}$ solution prior to isotopic analysis. $\mathrm{CL}$ and $\mathrm{BSE}$ images were utilized to select analytical points, avoiding complex internal structures and 
non-zircon grains. Imaging also provided a qualitative analysis of grain textures, morphologies, internal zoning patterns, and variations in CL color response.

$\mathrm{U}-\mathrm{Pb}$ analyses were conducted by laser ablation inductively coupled plasma mass spectrometry (LA-ICPMS) using a Photon Machines G2 excimer laser connected to an Element2 single-collector ICPMS. One spot was analyzed per grain using a laser beam diameter of 15 or 20 microns. Samples analyzed with a 15-micron beam include 17AVI03, 17AVI04, 17AVI06, 17AVI08, and 17AVI09. Samples analyzed with a 20micron beam include 17AVI02, 17AVI05, 17AVI07A, and 17AVI07B. The number of analyses per mount ranged from 109 to 380 analyses, dependent on the abundance of zircon extracted from each sample. Details of analytical methodologies are reported in DR Table 2 (analytical methods). Results of U-Pb zircon analyses are reported in DR Table 3.

Lu-Hf analyses were conducted using a Photon Machines G2 excimer laser connected to an NU Plasma HR multicollector ICPMS, utilizing the analytical methods described by Cecil et al. (2011) and Gehrels and Pecha (2014). Hf analysis utilizes a 40micron spot centered over the preexisting 20 or 15 -micron pit evacuated by $\mathrm{U}-\mathrm{Pb}$ analyses. Hf analyses were conducted on grains representative of each age group in each sample. The average uncertainty for analyses is 1.4 epsilon units $(2 \sigma)$. External precision, based on analysis of standards from the same mounts as unknowns, is 1.2 epsilon units $(2 \sigma)$. Analytical parameters are reported in DR Table 2.

\section{U-Pb Geochronologic and Hf Isotope Geochemical Results}

Results from all samples analyzed in this study are summarized on normalized U$\mathrm{Pb}$ age probability plots and $\mathrm{Hf}$-evolution plots (Figures 4-8). U-Pb and $\mathrm{Hf}$ analytical data for the Fourth Lake Formation can be found in DR Tables 1a and 2a. U-Pb and Hf analytical data tables for the Comox Formation can be found in DR Tables $1 b$ and $2 b$. To assist in interpretations of $\mathrm{Hf}$ data, $\mathrm{EHf}_{(\mathrm{t})}$ values (at the time of crystallization) within 5 units of depleted mantle (DM) are referred to as juvenile in composition, values between 
5 and 12 units below DM are considered intermediate, and values $>12$ units below DM are considered evolved following Bahlburg et al., (2011).

\subsection{U-Pb Geochronology and Lu-Hf Isotope Geochemistry of Paleozoic Samples}

Five samples from the Paleozoic Fourth Lake Formation were analyzed for this study totaling $1422 \mathrm{U}-\mathrm{Pb}$ ages and $162 \mathrm{EHf}_{(\mathrm{t})}$ values. Four samples (17AVI02, 17AVI03, 17AVI04, and 17AVI08) yielded $>300 \mathrm{U}-\mathrm{Pb}$ ages, whereas 17AVI05 yielded $109 \mathrm{U}-\mathrm{Pb}$ ages. All detrital zircon samples from the Fourth Lake Formation are fine to very fine sandstones, examples of outcrops and hand samples are presented in Figure 3 and sample locations are presented in Table 1.

Sample 17AVI03 yields $380 \mathrm{U}-\mathrm{Pb}$ ages with a dominant range of ages from 371$313 \mathrm{Ma}$ and yield a peak age of $344 \mathrm{Ma}$ (Fig. 4). This sample also contains older grains displaying minor age peaks at 1202, 1015, 691, 668, 597, 572, 536, 442, and $402 \mathrm{Ma}$ (Fig. 4). 17AVI03 also yielded several single ages of 2679, 2133, 1665, and $1465 \mathrm{Ma}$ (Fig. 4). 58 zircon grains were analyzed for Hf. Grains representative of the 344 Ma peak age yield predominantly juvenile $\mathrm{EHf}_{(\mathrm{t})}$ values ranging from +16 to +5 , while a single grain yields an evolved $\mathrm{EHf}_{(\mathrm{t})}$ value of $-17 . \mathrm{EHf}_{(\mathrm{t})}$ values for eight zircon grains that fall within an age range of 714 to $442 \mathrm{Ma}$ are intermediate to evolved, with values ranging from +2 to -19 . Six zircon grains older than $1000 \mathrm{Ma}$ yield intermediate to evolved $\mathrm{EHf}_{(\mathrm{t})}$ values ranging from +6 to -7 (Fig. 5).

Sample 17AVI02 yields $313 \mathrm{U}-\mathrm{Pb}$ ages with a single group of ages ranging from 365-310 Ma with a peak age of 339 Ma (Fig. 4). This sample did not yield any older grains. $\mathrm{EHf}_{(\mathrm{t})}$ values from 36 analyses from sample 17AVI02 yield a dominantly juvenile signature ranging from +17 to +5 , with two analyses yielding an evolved signature with values of -15 and -11 (Fig. 5).

Sample 17AVI04 yields $313 \mathrm{U}-\mathrm{Pb}$ ages with a dominant range of ages from 364$316 \mathrm{Ma}$ with a corresponding peak age of $336 \mathrm{Ma}$ (Fig. 4). This sample yields four older grains with ages of 2802, 941, 492, and $374 \mathrm{Ma}$ (Fig. 4). $36 \mathrm{Hf}$ analyses were conducted 
on zircon grains from sample 17AVI04. Grains within the main age group yield a dominantly juvenile $\mathrm{EHf}_{(\mathrm{t})}$ signature with values ranging from +15 to +6 . Older grains, from oldest to youngest, yield $\mathrm{EHf}_{(\mathrm{t})}$ values of $-1,0,+4$, and +15 (Fig. 5).

Sample 17AVI05 yields $109 \mathrm{U}-\mathrm{Pb}$ ages with a dominant group of ages ranging from 359-311 Ma (peak age of $331 \mathrm{Ma}$ ) (Fig. 4). Two grains older than 359 Ma yield ages of $2749 \mathrm{Ma}$ and $1612 \mathrm{Ma}$ (Fig. 4). $32 \mathrm{Hf}$ analyses were conducted on this sample with $\mathrm{EHf}_{(\mathrm{t})}$ values for zircon grains from the main cluster, yielding primarily juvenile values ranging from +15 to +5 . The two older grains yield $\mathrm{EHf}_{(\mathrm{t})}$ values of +7 and +3 , respectively (Fig. 5).

Sample 17AVI08 yielded $307 \mathrm{U}-\mathrm{Pb}$ ages with a prominent group of ages ranging from 361-281 Ma, with a corresponding peak age of $317 \mathrm{Ma}$, and three single-grain ages of 1025, 273, and $270 \mathrm{Ma}$ (Fig. 4). This is only sample from the Fourth Lake Formation yielding ages younger than $310 \mathrm{Ma} .41 \mathrm{Hf}$ analyses were conducted on sample 17AVI08, which yields a predominately juvenile signature with $\mathrm{EHf}_{(\mathrm{t})}$ values ranging from +17 to +2 for grains within the range of 361-281 Ma, whereas the single older grain at $1025 \mathrm{Ma}$ yields a $\mathrm{EHf}_{(\mathrm{t})}$ value of +5 (Fig. 5).

\subsubsection{Summary of results from Paleozoic samples}

All samples yield a single dominant peak with corresponding peak ages of 344, 339, 336, 331, and $317 \mathrm{Ma}$, which shows a trend of younging to the north (Fig. 4). Grains older than $371 \mathrm{Ma}$ comprise $2.4 \%$ of the total grains analyzed. Combining all five samples yields a peak age of $337 \mathrm{Ma}$ (Fig. 4). The Hf isotopic composition of zircon grains from Fourth Lake Formation yield juvenile to intermediate signatures, with most $\mathcal{E H f}_{(t)}$ values in the range of +17 to +9 . Zircon grains that are older than the main cluster

of ages, yield $\mathrm{EHf}_{(\mathrm{t})}$ values that range from intermediate to evolved, with a range of +5 to -20 (Fig. 5).

\subsection{U-Pb Geochronology and Lu-Hf Isotope Geochemistry of the Comox Formation}


Four samples from the Upper Cretaceous Comox Formation were analyzed for this study, totaling $1055 \mathrm{U}-\mathrm{Pb}$ ages and $240 \mathrm{EHf}_{(\mathrm{t})}$ values. Three samples (17AVI07A, 17AVI07B, and 17AVI09) each yielded $>300 \mathrm{U}-\mathrm{Pb}$ ages, whereas 17AVI06 yielded 118 ages. All detrital zircon samples from the Comox Formation are cobble to pebble conglomerates, examples of outcrops and hand samples of the Comox Formation are present in Figure 3 and sample locations are presented in Table 1.

Sample 17AVI06 yielded $118 \mathrm{U}-\mathrm{Pb}$ ages with prominent peak ages at $341 \mathrm{Ma}$ and $202 \mathrm{Ma}$ (Fig. 6). A minor peak of 196 Ma occurs on the young side of the 202 Ma peak (Fig. 6). A subordinate group of four ages ranges from 164-158 Ma and yields a peak age of 159 Ma. 17AVI06 also yields single grain ages of 263, 223, 128, and 87 Ma. No grains older than $370 \mathrm{Ma}$ are observed in this sample. $26 \mathrm{Hf}$ analyses were conducted on sample 17AVI06. Grains within the main age groups, yield juvenile $\mathrm{EHf}_{(\mathrm{t})}$ values ranging from +15 to +6 (Fig. 7). Three Hf analyses were conducted on grains within the subordinate younger age group and yield $\mathrm{EHf}_{(\mathrm{t})}$ values ranging from +13 to +9 . Two single grains with ages of $263 \mathrm{Ma}$ and $87 \mathrm{Ma}$ yield $\mathrm{EHf}_{(\mathrm{t})}$ values of +10 and +13 , respectively (Fig. 7).

Sample 17AVI07A yielded $314 \mathrm{U}-\mathrm{Pb}$ ages that belong to two different groups. The older group ranges from 217-184 Ma, with a peak age of 194 Ma (Fig. 6). The younger group yields an age range of 180-159 Ma, with a peak age of $166 \mathrm{Ma}$ (Fig. 6). Two single grain ages of $363 \mathrm{Ma}$ and $360 \mathrm{Ma}$ are observed. $33 \mathrm{Hf}$ analyses were conducted on this sample with both prominent groups of ages yielding predominantly juvenile $\operatorname{EHf}_{(t)}$ values ranging from +13 to +5 (Fig. 7). The two older grains observed in this sample yield $\mathrm{EHf}_{(\mathrm{t})}$ values of +13 and +10 (Fig. 7).

Sample 17AVI07B yields $314 \mathrm{U}-\mathrm{Pb}$ ages with two equally prominent age peaks of $197 \mathrm{Ma}$ and $167 \mathrm{Ma}$, and a minor peak age of $83 \mathrm{Ma}$ (Fig. 6). A scattering of single grains yields older ages of 365, 356, 349, and $321 \mathrm{Ma}$ (Fig. 6). $39 \mathrm{EHf}_{(\mathrm{t})}$ analyses from sample 17AVI07B were generated, with $\mathrm{EHf}_{(\mathrm{t})}$ values for the two prominent age groups yielding $\operatorname{EHf}_{(\mathrm{t})}$ values ranging from +14 to +7 (Fig. 7). $\operatorname{EHf}_{(\mathrm{t})}$ analyses of the younger 83 
Ma grains yield values of +7 (Fig. 7). Older ages, encompassing grains from 365 to 321 Ma, yield $\mathrm{EHf}_{(\mathrm{t})}$ values ranging from +13 to +9 (Fig.7).

Sample 17AVI09 yields $312 \mathrm{U}-\mathrm{Pb}$ ages with a dominant peak age of $152 \mathrm{Ma}$ (Fig. 6). A younger pronounced peak is observed with a corresponding peak age of $87 \mathrm{Ma}$ (Fig. 6). A minor peak of $165 \mathrm{Ma}$ is observed on the old side of the dominant $152 \mathrm{Ma}$ age group (Fig. 6). A subordinate group yields an age range of 360-340 Ma with a peak age of $356 \mathrm{Ma}$ (Fig. 6). Several single-grain ages range from 308-209 Ma. Four single-grains are older than $356 \mathrm{Ma}$ and yield ages of 1712, 529, 396, and $381 \mathrm{Ma}$. Sample 17AVI09 yielded $142 \mathrm{Hf}$ analyses with the majority of grains displaying a juvenile $\mathrm{EHf}_{(\mathrm{t})}$ signature (Fig. 7). Zircon grains representative of the 152 Ma peak age yield $\varepsilon H f_{(t)}$ values ranging from +16 to +6 , with a single grain yielding an evolved value of -11 (Fig. 7). Grains from the minor group of $165 \mathrm{Ma}$ yields $\mathrm{EHf}_{(\mathrm{t})}$ values of +14 to +6 , with a single grain yielding a value of -6 (Fig. 7). Analyses from the group of ages representing the 87 Ma peak age yield $\mathrm{CHf}_{(\mathrm{t})}$ values ranging from +13 to +8 (Fig. 7). Zircons within the age range of 360$340 \mathrm{Ma}$ yield $\mathrm{EHf}_{(\mathrm{t})}$ values ranging from +11 to +5 (Fig. 7), whereas grains of a broad range of ages from 308-209 Ma have $\mathcal{E H f}_{(\mathrm{t})}$ values ranging from +15 to +3 (Fig. 7). Single grains with ages of $529 \mathrm{Ma}$ and $396 \mathrm{Ma}$ yield positive $\mathrm{EHf}_{(\mathrm{t})}$ values of +1 and +9 , respectively (Fig. 7).

A single sample (07JBM06) of the Comox Formation outcropping on Saltspring Island (Fig. 1) was collected by Brian Mahoney, and is included in this study. This sample yields dominant age peaks of 367, 196, and 155 Ma (Fig.6). Six grain ages older than $1.0 \mathrm{Ga}$ are 2678, 1828, 1134, 1072, 1040, and $1037 \mathrm{Ma}$ (Fig. 6). Younger grains that are less than 110 Ma yield ages of 108, 87, with two ages at $81 \mathrm{Ma}$ (Fig. 6). No Hf isotopes were collected for sample 07JBM06. The U-Pb data table for sample 07JBM06 can be found in DR. Table 1b.

\subsubsection{Summary of results from Comox samples}


Combining all samples described above yields peak ages of 365, 195, 166, 153, and $91 \mathrm{Ma}$ (Fig. 6). The Hf isotopic composition of zircon grains in samples from the Comox are juvenile to intermediate, with most $\mathrm{EHf}_{(\mathrm{t})}$ values in the range of +15 to +5 (Fig. 7).

\section{Provenance of the Fourth Lake Formation}

\subsection{Provenance of Paleozoic zircons}

Detrital zircons from five samples of the Fourth Lake Formation yield predominantly Paleozoic ages with a prominent age range from 380-280 Ma, and a peak age of $337 \mathrm{Ma}$ (Figures. 4 and 5). Two previously analyzed detrital zircon samples from Ruks (2015), located farther east than samples in this study (Fig. 1) primarily yield ages younger than $330 \mathrm{Ma}$ (Fig. 4). Individual samples, from this study, and detrital samples from Ruks (2015), yield peak ages of 344, 339, 336, 331, 317, 320, and 312 Ma from south to north, suggesting that peak ages for Paleozoic detrital samples on Vancouver Island young northward (Figures 1 and 4).

Comparing ages from this study with igneous zircon data from Ruks (2015) yields a similar range of ages from 380-280 Ma (Fig. 4). Given the similar overlap in the total range of ages, detrital zircons within the Fourth Lake are interpreted to have been derived from rocks of the Sicker Group as well as younger igneous rocks of the Buttle Lake Group.

$\mathrm{U}-\mathrm{Pb}$ igneous zircon ages from Ruks (2015) indicate an apparent northward arc migration, but also display a magmatic gap from 334-314 Ma (Figures 1 and 4). Detrital zircon $\mathrm{U}-\mathrm{Pb}$ peak ages from the Fourth Lake Formation and detrital samples from Ruks (2015) also show a similar trend of younging to the north with most ages falling within the magmatic gap (Fig. 4). Considering detrital samples contain a large proportion of ages within the magmatic gap, a source for 334-314 Ma grains must have been present during deposition of the Fourth Lake, but are now most likely buried beneath Karmutsen basalts. The similarities between igneous U-Pb ages from Ruks (2015) and the range of 
ages from 380-280 Ma observed in the Fourth Lake Formation supports derivation from igneous rocks on Vancouver Island.

Comparison of $\mathrm{Hf}$ isotope data acquired in this study and $\mathrm{Nd}$ isotope data from Ruks (2015) provides further support for derivation from igneous rocks on Vancouver Island. In order to compare $\mathcal{E N d}_{(t)}$ and $\mathcal{E H f}_{(t)}$ values, a conversion to $\mathcal{E H f}_{(\mathrm{t})}$ is used $\left(\mathcal{E H f}_{(\mathrm{t})}=1.36 \mathrm{x} \varepsilon \mathrm{Nd}_{(\mathrm{t})}+2.95\right)$, as described by Vervoort et al. (1999). Converted $\mathcal{E} \mathrm{Hf}_{(\mathrm{t})}$ values from Ruks (2015) yield values for samples with ages of ca.360 Ma ranging from +11 to $+9,+11$ for a single rock with an age of ca. $317 \mathrm{Ma}$, and +12 to +8.7 for rocks with ages of ca. $300 \mathrm{Ma}$ (Fig. 5). Converted Nd isotope data for Paleozoic igneous rocks reported in Ruks (2015) represent juvenile compositions associated with the Paleozoic southern Wrangellia arc system from 370-280 Ma (Fig. 5).

$\mathrm{U}-\mathrm{Pb}$ ages and $\mathrm{Hf}$ isotope data presented for detrital zircons from the Fourth Lake Formation yield a similar age range, and similar $\mathrm{EHf}_{(\mathrm{t})}$ values ranging consistently from +17 to +10 (Figures 4 and 5). Zircons from the Fourth Lake show a decrease in the abundance of intermediate $\mathrm{EHf}_{(\mathrm{t})}$ values from 325-290 Ma, similarly to data from Ruks (2015) (Fig. 5). Similar trends and overlap in juvenile Hf composition from converted $\mathrm{Nd}$ isotope data from Ruks (2015) further support the interpretation of the Fourth Lake Formation sourcing zircon grains from the Sicker Group and igneous rocks of the Buttle Lake Group (Fig. 5).

\subsection{Neoproterozoic to Paleozoic zircons}

The Fourth Lake Formation also contains 49 grains with ages ranging from 2802$442 \mathrm{Ma}$ with corresponding $\mathrm{EHf}_{(\mathrm{t})}$ values ranging from +13 to -20 . These grains are subdivided into four age clusters: 2802-942 Ma, 714-681 Ma, 586-537 Ma, and 492-442 Ma (Fig. 5). A majority of these grains come from sample 17AVI03, which also yields the oldest peak age of $344 \mathrm{Ma}$ (Fig. 4). The lack of similar old ages from igneous rocks of Vancouver Island suggests that such rocks may exist, but have not been recognized, or that the grains were shed from a source region that is not part of southern Wrangellia as 
presently exposed. The occurrence of several zircons from the Fourth Lake Formation that yield marginally intermediate to evolved Hf signatures from 380 to $290 \mathrm{Ma}$ also suggests the presence of older crustal material. Further discussion regarding ages older than $380 \mathrm{Ma}$ and interpretations regarding intermediate Hf signatures in southern Wrangellia are presented in section 7.1.

\section{Provenance of the Comox Formation}

\subsection{Paleozoic zircons}

Detrital zircons yielding $\mathrm{U}-\mathrm{Pb}$ ages from 384-284 Ma with corresponding juvenile $\mathrm{EHf}_{(\mathrm{t})}$ values from the Comox Formation are similar to grains from the Fourth Lake Formation. Similarities in $\mathrm{U}-\mathrm{Pb}$ ages and $\mathrm{EHf}_{(\mathrm{t})}$ values indicate derivation from Paleozoic igneous rocks of southern Wrangellia (Figures 6, 7, and 8). The Comox Formation primarily yields older Paleozoic ages from 381-335 Ma, which indicates a greater contribution of igneous rocks from the Sicker Group. An explanation for a larger influx of older Sicker Group age zircons in the Comox is in part due to these samples being in close proximity to igneous rocks related to the Saltspring Intrusion (Fig. 1). This geographic interpretation indicates that Paleozoic rocks on Vancouver Island may not have been entirely buried by the Triassic Karmutsen basalts, which would allow for primary deposition of older Sicker Group zircons into the Comox Formation. However, field observations of the Comox Formation bearing clasts of the Fourth Lake (Figure 3, pictures $\mathrm{C}$ and $\mathrm{D}$ ), and the presence of grains within the magmatic gap (ca. 334-314 Ma) indicates recycling of grains from Paleozoic sedimentary units as well.

\subsection{Early to Late Triassic zircons}

Ages that fall outside of dominant peak ages from the Comox Formation include grains younger than $280 \mathrm{Ma}$, which consists of only 12 single grain ages ranging from 277-223 Ma (Fig. 6) with corresponding $\mathrm{EHf}_{(\mathrm{t})}$ values ranging from +12 to +3 (Fig. 7). The source of grains with ages from 277-223 Ma is uncertain given the lull in magmatism in southern Wrangellia during this time period. The only magmatism recorded in 
southern Wrangellia during this age range is the eruption of the Karmutsen flood basalts, which occurred from 232-225 Ma (Greene et al., 2010), but zircon is rare in basaltic rocks.

\subsection{Late Triassic to Middle Jurassic zircons}

$\mathrm{U}-\mathrm{Pb}$ ages and $\mathrm{Hf}$ isotope data for grains in the age range of 217-160 Ma with corresponding $\mathrm{EHf}_{(\mathrm{t})}$ values from +15 to +5 were probably sourced from igneous rocks of the Jurassic Bonanza Group. Igneous rocks from the Bonanza Group yield ages ranging from 202-165 Ma, with previous geochemical data indicating a juvenile to intermediate signature (Isachsen,1987; Debari et al., 1999; Paulson, 2010). Similarities observed in ages and geochemical data from previous studies, described in section 2.2.2 (Debari et al., 1999; Friedman and Nixon, 2005; Paulson, 2010), lead to an interpretation for these grains originating from juvenile igneous rocks of the Jurassic Bonanza Group on Vancouver Island.

\subsection{Late Jurassic to Cretaceous Zircons}

Some of the samples from the Comox Formation (17AVI06, 17AVI07A, and 17AVI07B) contain few or no ages from 159-78 Ma, which we attribute to the depositional setting of topographically trapped basins sourcing very local detritus. Samples that do contain ages in this range yield $\mathrm{EHf}_{(\mathrm{t})}$ values from +14 to +6 (Fig.7). Detrital zircons from the Comox Formation have previously been interpreted to have been shed from the Coast Mountain Batholith, which suggests that the Nanaimo basin formed close to the Coast Mountains (Mustard, 1994; Mustard et al., 1995; Mahoney et

al., 1999; Katnick and Mustard, 2003; Matthews et al., 2017). Matthews et al. (2017) suggested derivation from the central CMB because of consistencies in timing and volume of magmatic flux events in the central CMB [160-140 Ma, 120-78 Ma, and 55-48 Ma (Gehrels et al., 2009)] correlating to peak ages. Our data support this interpretation in that the range of ages and combined peak ages of $152 \mathrm{Ma}$ and $86 \mathrm{Ma}$ are similar to samples $\mathrm{CO} 1$ and $\mathrm{CO} 2$ from Matthews et al. (2017) (Fig. 6). Further support from Hf 
data for this range of ages are similar to $\mathrm{EHf}_{(\mathrm{t})}$ values $(+16$ to -3$)$ reported from the central CMB (Fig. 7) (Cecil et al., 2011). Although an abundance of intermediate to evolved $\mathrm{EHf}_{(\mathrm{t})}$ values are present in the central CMB, which is attributed to plutons intruding older continental crust, an abundance of juvenile values are also observed (Fig. 7) (Cecil et al., 2011). Our data is less consistent with timing of magmatic flux events in the southern CMB [161-148 Ma, 114-102 Ma, and 85-70 Ma (Cecil et al., 2018)] considering a lack of ages from 120-100 Ma observed in the Comox Formation (Fig. 7). We interpret a source for ages in the range of 159-78 Ma to be derived from the central CMB similar to interpretations of Matthews et al. (2017).

\section{Discussion}

\subsection{Possible connections with the Alexander terrane}

The presence of $>380$ Ma detrital zircons in the Fourth Lake Formation and the presence of several grains with intermediate to evolved epsilon $\mathrm{Hf}$ composition supports previous suggestions that some sediment was derived from pre-Late Devonian crust (Samson et al., 1990; Massey, 1995a, b, c; Ruks, 2015). One possibility is that crust of this age, or sediments containing pre-Late Devonian detrital zircons, is present on Vancouver Island. This possibility is difficult to evaluate given that such rocks have not been recognized.

A second alternative is that these older crustal components were derived from the Alexander terrane, given that the Wrangellia and Alexander terranes are interpreted to have been near each other during late Paleozoic time (Gardner et al., 1988, Israel et al., 2014; Beranek et al., 2014). Three distinct portions of the Alexander terrane have reported $\mathrm{U}-\mathrm{Pb}$ ages and $\mathrm{Hf}$ isotope data, which include the Saint Elias Mountains region (Beranek et al., 2013a and b), Southeast Alaska (Cecil et al., 2011; White et al., 2015), and the Banks Island assemblage (Tochilin et al., 2014) (Fig. 1). U-Pb data and Hf isotope data from the Alexander terrane is displayed in Figures 9 and 10. 
The most likely connections are with the Banks Island and Saint Elias portions of the terrane given the interpretation that southern Wrangellia was located next to northern Wrangellia and northern Alexander prior to Early Cretaceous time (Plafker et al., 1989; Tochilin et al., 2014; White et al., 2015).

\subsection{Paleozoic zircons}

Assuming a mixture of older sediment from the Banks Island assemblage and juvenile melt from the subduction related magmatism in southern Wrangellia, corresponding $\mathrm{EHf}_{(\mathrm{t})}$ values of zircons crystallized from this mixed melt would yield a marginally intermediate signature. $\mathrm{EHf}_{(\mathrm{t})}$ values from this study and previous geochemical studies of southern Wrangellia have consistently observed this trend of more evolved melt compositions during early arc construction (Figures 9 and 10) (Samson et al., 1990; Massey, 1995a, b, c; Ruks, 2015). Attributing that trend to a sediment source containing pre-370 Ma zircons from the Banks Island assemblage would support this interpretation, considering that zircons from the Banks Island assemblage metaclastic rocks are of a broad range of ages from $3.0 \mathrm{Ga}-380 \mathrm{Ma}$, with intermediate to evolved $\mathrm{EHf}_{(\mathrm{t})}$ values (Figures 9 and 10). We propose sediment was dispersed from the (present day) northern Alexander terrane, which contaminated juvenile melt of (present day) southern Wrangellia. This interpretation adds further support for evolved melts during early arc construction.

\subsection{Paleoproterozoic to Late Devonian zircons}

Several grains with older ages are observed in southern Wrangellia and yield ages from 2802-380 Ma. These grains are presented in four clusters with ages ranging from 2802-942 Ma, 714-682 Ma, 586-536 Ma, and 490-440 Ma. Corresponding EHf (t) $_{\text {values }}$ for these clusters range from +2 to -19 (Fig. 9). An overlap in age and Hf isotope signature for these clusters suggest that these older grains may have been shed from the Alexander Terrane, considering igneous rocks with ages older than 370 Ma have not been recognized on Vancouver Island. 


\section{Tectonic Implications for Paleozoic Wrangellia}

Previous workers have suggested that Wrangellia originated at the margin of the Paleo-Pacific and Paleo-Arctic realms while developing relatively close to the Alexander Terrane from Devonian through Permian time (Soja, 1994; Bazard et al., 1995; Gehrels et al., 1996; Butler et al., 1997; Soja and Krutikov, 2008; Colpron and Nelson, 2009, 2011; Miller et al., 2011; Beranek et al., 2012, 2013a, 2013b; Nelson et al., 2013; Beranek; 2014; Israel et al., 2014). With new U-Pb ages and Hf isotope date from the Fourth Lake and Comox Formations, and previous interpretations (Colpron and Nelson, 2007; Colpron and Nelson, 2009; Nelson et al., 2013; Beranek et al., 2014; Israel et al., 2014; Ruks, 2015) indicating potential ties to the Alexander terrane, we offer a new tectonic model for the development of the Paleozoic southern Wrangellia arc system (Fig. 11, A$\mathrm{H})$.

380 to 370 Ma - The "northwest passage" (Colpron and Nelson, 2009; Nelson et al., 2013) has extruded the Alexander terrane west out of the Paleo-Arctic into the NE Paleo-Pacific realm. An east dipping subduction zone is present outboard of western Laurentia with the overriding plate bearing the Alexander terrane, which has shed detritus across adjacent oceanic crust. The distance of the subduction zone to the Alexander Terrane is unknown, however this subduction zone is where the nascent Sicker Arc will form (Fig. 11, A).

$370 \mathrm{Ma}$ - Subduction initiated arc development between oceanic plate boundaries generating IAT, L-IAT, and minor E-MORB type rocks of the Sicker arc, signifying the beginning of the Paleozoic southern Wrangellia arc system. Subduction related magmatism is contaminated with sediment derived from the nearby Alexander Terrane from the upper crust, however the proximity of the Alexander terrane is uncertain (Fig. $11, \mathrm{~B})$.

360-350 Ma - A slab-rollback event occurs, after the Sicker arc reaches full maturity, which rifts the pre-existing arc and subsequently forms a back-arc spreading 
center and shuts off the Sicker arc (Ruks, 2015). The spreading center in southern Wrangellia propagates toward the north (Israel et al., 2014) (Fig. 11, C).

$350 \mathrm{Ma}-\mathrm{A}$ second pulse of bimodal arc magmatism is initiated beneath the southern Wrangellia arc system with the emplacement of VMS type deposits within the back-arc of Wrangellia (Ruks, 2015). The earliest deposits of the Buttle Lake Group, ribbon cherts associated with the Fourth Lake Formation, are deposited in the back-arc basin and on portions of the rifted fragments of the Sicker arc (Ruks, 2015). Arc magmatism related to northern Wrangellia is initiated (Israel et al., 2010) (Fig. 11, D).

340-330 Ma - Continued arc magmatism connects northern and southern Wrangellia, while volcanic centers in southern Wrangellia migrate northward (Ruks, 2015). Deposition of low-energy deep marine sediments of the Fourth Lake Formation persists (Fig. 11, E).

$330 \mathrm{Ma}$ - Subduction reversal occurs, changing from east dipping subduction to west dipping subduction. This change in subduction initiates the encroachment of the Alexander Terrane toward Wrangellia (Beranek et al., 2014). Deposition of deep marine sediments of the Fourth Lake Formation continues (Fig. 11, F).

310 - 300 Ma - Wrangellia and Alexander collide (Beranek et al., 2014). Collision stitches the northern portion of Wrangellia and Alexander together, as indicated by emplacement of the Barnard Glacier Pluton (307 Ma), Centennial Ridge Pluton (304 Ma), and the Logan Glacier Pluton (307 Ma) after a slab breakoff event (Beranek et al., 2014). Arc magmatism continues in southern Wrangellia during the collision. Continued normal arc type magmatism is observed in the northern portion of southern Wrangellia suggested by emplacement of 310-300 Ma igneous rocks near the Buttle Lake uplift (Ruks, 2015) (Fig. 11, G).

300 - 280 Ma - After collision, subduction shifts behind the Alexander terrane, as observed in emplacement of the Donjek Glacier Batholith (286-284 Ma), the Steele Glacier Pluton (291 Ma), and other granitoids with ages from 290 to $280 \mathrm{Ma}$ in the 
Alexander terrane (Beranek et al., 2014) and from minor magmatic activity observed in Wrangellia (Ruks, 2015). In Early Permian time ( 280 Ma) a fragment from the Alexander Terrane, the Admiralty subterrane, clogs the subduction zone, which finally shuts off all arc magmatism within Paleozoic Wrangellia (Beranek et al., 2014) (Fig. 11, $\mathrm{H})$.

\section{Conclusions}

This study has conducted the first large-n detrital zircon analysis of Paleozoic strata from southern Wrangellia. The primary conclusion of our study is that the Paleozoic southern Wrangellia arc system was a juvenile intra-oceanic arc that was active sporadically for $\sim 90$ million years, beginning at $370 \mathrm{Ma}$ and shutting off close to $280 \mathrm{Ma}$. $\mathrm{U}-\mathrm{Pb}$ ages of detrital and igneous zircons record somewhat different histories, with detrital zircon ages peaking at $337 \mathrm{Ma}$ whereas igneous ages (Ruks, 2015) peak at 358 Ma and 305 Ma with a magmatic gap from 334-314 Ma. Igneous rocks with ages of ca. 334-314 Ma are interpreted to have been widespread but were covered by Upper Triassic Karmutsen basalts. Both detrital and igneous geochronology record northward arc migration from 340 to $320 \mathrm{Ma}$ (Ruks, 2015).

Hf isotope analyses of Paleozoic rocks record a juvenile Hf signature throughout the life of the Paleozoic southern Wrangellia arc system, however moderately intermediate Hf signatures are observed during early arc development. We propose intermediate Hf signatures from Paleozoic age zircons are sourced from igneous rocks of southern Wrangellia enriched by older sediment dispersed from the Alexander terrane. Mixing of an older sediment component is further supported by the presence of grains older than $380 \mathrm{Ma}$ incorporated into the Fourth Lake Formation. This suggests the presence of a Precambrian crustal component, which we suggest may belong to the Alexander terrane.

This study has also provided new geochronological and geochemical data for the Upper Cretaceous Nanaimo Group. Sampling of the Comox Formation was successful in 
recognizing Paleozoic zircons derived from southern Wrangellia, which yield additional $\mathrm{EHf}_{(\mathrm{t})}$ values for characterization of the Paleozoic southern Wrangellia arc system. Analyses of the Comox Formation also yield U-Pb ages and Hf isotope data that suggest derivation from the Bonanza arc on Vancouver Island. $\mathrm{U}-\mathrm{Pb}$ ages from the Comox Formation also reveal sources from the central Coast Mountains Batholith, which is consistent with previous interpretations of Matthews et al. (2017).

\section{Figure Captions}

Figure 1. Generalized geologic map of Vancouver Island (Modified from Massey, 2005a and $b$, from the BC Geologic Survey). Inset map indicates relevant terranes of the northern Cordillera, location of study area, and general locations for three sub-divisions of the Alexander Terrane: SEM - Saint Elias Mountain region (Beranek et al., 2013a, 2013b), SE Alaska (Gehrels et al., 1996; Tochilin et al., 2014; White et al., 2015), and BIM - Banks Island Assemblage (Tochilin et al., 2014). Abbreviations for displayed tectonic components on inset map: YA - Yakutat; $\mathrm{CH}$ - Chugach; CPC - Coast Plutonic Complex; PE - Peninsular; WR - Wrangellia; AX - Alexander. Sample locations for this study are denoted with squares. Colored circles are used to represent samples from Ruks (2015). Yellow Hexagon represent sample location for samples from Matthews et al., (2017). Dashed ellipses mark the area of uplifts.

Figure. 2 Generalized stratigraphic column and interpreted sample positions for strata from Vancouver Island, B.C. (adapted from Massey, 1987). Stratigraphic nomenclature is from Massey (1995b). Geologic time scale is from Walker et al. (2012). Strat column ages are displayed in millions of years.

Figure 3. Select outcrop and hand sample photos from the Fourth Lake Formation (photos A, B, E, F, and G) and the Comox Formation (photos C and D). Further sample descriptions displayed in Table 1. (A) 17AVI01 hand sample displaying interbedding of chert and medium grained sand. (B) Outcrop of sample 17AVI04 consisting of chert and 
interbedded layers of silt to fine grained sand. (C) Large pebble clast of interbedded chert and sand, indicative of the Fourth Lake formation, within the Comox Formation (sample 17AVI06). (D) Smaller pebble clast of interbedded chert and sand, indicative of the Fourth Lake Formation, within the Comox Formation (Sample 17AVI07A). (E) Outcrop photo from sample 17AVI03 displaying layering of chert and interbedded fine grained sandstone. (F) Close up outcrop photo of sample 17AVI05, a layer of silt to fine sand at the millimeter scale. (G) Hand sample photo of sample 17AVI08, centimeter scale beds of fine to medium grained sandstone interbedded with chert.

Figure. 4 Normalized age distribution diagram for detrital zircons from the Fourth Lake Formation and igneous zircon U-Pb ages from Ruks (2015) separated into two curves based on geographic location as expressed in Figure. 1. Two detrital samples (08TR017 and 08TR019) from Ruks (2015) are separated from igneous samples in order to compare with detrital samples in this study. Main peaks are noted for each sample in millions of years. Number of samples within Ruks (2015) distributions denoted with "N", number of analysis in each curve denoted with " $n$ ". Proportions of $>400$ Ma ages have been vertically exaggerated by a factor of eight relative $<400$ Ma grains. Sample locations are generally placed on a map of Vancouver Island, LAT/LONG coordinates displayed to the right for individual samples.

Figure. $5 \mathrm{U}-\mathrm{Pb}$ and $\mathrm{EHf}_{(\mathrm{t})}$ values from the Fourth Lake Formation. Converted $\mathrm{END}_{(\mathrm{t})}$ values from Ruks (2015) are displayed as triangles. Lower curve is a probability curve for all Fourth Lake samples from this study. Ages $>400 \mathrm{Ma}$ are vertically exaggerated by a factor of five relative to $<400 \mathrm{Ma}$ grains. Upper plot shows $\mathrm{EHf}_{(\mathrm{t})}$ values for individual samples. Reference lines on the Hf plot are as follows: DM-depleted mantle, calculated using ${ }^{176} \mathrm{Hf} /{ }^{177} \mathrm{HfO}=0.283225$ and ${ }^{176} \mathrm{Lu} /{ }^{177} \mathrm{HfO}=0.038512$ (Vervoort and BlichertToft, 1999); CHUR — chondritic uniform reservoir, calculated using ${ }^{176} \mathrm{Hf} /{ }^{177} \mathrm{Hf}=$ 0.282785 and ${ }^{176} \mathrm{Lu} /{ }^{177} \mathrm{Hf}=0.0336$ (Bouvier et al., 2008). Black arrows show interpreted crustal evolution trajectories assuming present-day ${ }^{176} \mathrm{Lu} /{ }^{177} \mathrm{Hf}=0.0093$ (Vervoort and Patchett,1996; Vervoort et al., 1999; Bahlburg et al., 2011). 
Figure. 6 Normalized age distribution diagram for detrital zircons from the Comox Formation compared to Comox Formation samples from Matthews et al. (2017) (CO1 and $\mathrm{CO} 2$ ). Main peaks are noted for each sample in millions of years. Proportions of $>600$ Ma grains have been vertically exaggerated by a factor of ten relative to $<600 \mathrm{Ma}$ grains (VE). Number of analyses in each sample denoted with " $n$ ".

Figure. $7 \mathrm{U}-\mathrm{Pb}$ and $\mathrm{EHf}_{(\mathrm{t})}$ values from the Comox Formation, central Coast Mountain Batholith $\mathcal{E H f}_{(\mathrm{t})}$ values are from Cecil et al. (2011). Filled grey curve is the age distribution for the Comox Formation, which includes samples from Matthews et al. (2017). The pink age distribution curve for the Central Coast Mountains is from Gehrels et al. (2009) and Cecil et al. (2011). Filled purple age-distribution curve for the Southern Coast Mountains is from Cecil et al. (2018). Dashed magmatic flux curves for the Central Coast Mountains (Gehrels et al., 2009) and Southern Coast Mountain Batholith (Cecil et al., 2018) are represented with dashed lines. Reference lines on the Hf plot are as follows: $\mathrm{DM}$-depleted mantle, calculated using ${ }^{176} \mathrm{Hf} /{ }^{177} \mathrm{HfO}=0.283225$ and ${ }^{176} \mathrm{Lu} /{ }^{177} \mathrm{HfO}=$ 0.038512 (Vervoort and Blichert-Toft,1999); CHUR — chondritic uniform reservoir, calculated using ${ }^{176} \mathrm{Hf} /{ }^{177} \mathrm{Hf}=0.282785$ and ${ }^{176} \mathrm{Lu} /{ }^{177} \mathrm{Hf}=0.0336$ (Bouvier et al., 2008). Black arrows show interpreted crustal evolution trajectories assuming present-day ${ }^{176} \mathrm{Lu} /{ }^{177} \mathrm{Hf}=0.0093$ (Vervoort and Patchett, 1996; Vervoort et al., 1999; Bahlburg et al., 2011).

Figure. $8 \mathrm{U}-\mathrm{Pb}$ and $\mathrm{EHf}_{(\mathrm{t})}$ values from the Fourth Lake Formation and the Comox Formation analyzed in this study. Lower curves are normalized probability curves. Upper plot shows $\mathrm{EHf}_{(\mathrm{t})}$ values for all samples analyzed. Reference lines on the Hf plot are as follows: DM—depleted mantle, calculated using ${ }^{176} \mathrm{Hf} /{ }^{177} \mathrm{HfO}=0.283225$ and ${ }^{176} \mathrm{Lu} /{ }^{177} \mathrm{HfO}=0.038512$ (Vervoort and Blichert-Toft, 1999); CHUR—chondritic uniform reservoir, calculated using ${ }^{176} \mathrm{Hf} /{ }^{177} \mathrm{Hf}=0.282785$ and ${ }^{176} \mathrm{Lu} /{ }^{177} \mathrm{Hf}=0.0336$ (Bouvier et al., 2008). Black arrows show interpreted crustal evolution trajectories assuming presentday ${ }^{176} \mathrm{Lu} /{ }^{177} \mathrm{Hf}=0.0093$ (Vervoort and Patchett,1996; Vervoort et al., 1999; Bahlburg et al., 2011). 
Figure. $9 \mathrm{U}-\mathrm{Pb}$ ages and $\mathrm{EHf}_{(\mathrm{t})}$ values for detrital and igneous zircons from Southern Wrangellia and the Alexander terrane. Lower curves show age distributions of detrital zircon samples from Southern Wrangellia (Ruks, 2015; this study), South-East (SE) Alaska (Tochilin et al., 2014; White et al., 2015), the Banks Island Assemblage (Tochilin et al., 2014), and the Saint Elias Mountains region (Beranek et al., 2013a, 2013b). Peak ages displayed in millions of years. Note variable vertical exaggeration (VE) of older than $800 \mathrm{Ma}$ ages. Upper plot shows $\mathrm{EHf}_{(\mathrm{t})}$ values from Southern Wrangellia (this study) SE Alaska (Tochilin et al., 2014; White et al., 2015), Banks Island Assemblage (Tochilin et al., 2014), and the Saint Elias Mountains region (Beranek et al., 2013a, 2013b). Reference lines on the Hf plot are as follows: DM—depleted mantle, calculated using ${ }^{176} \mathrm{Hf} /{ }^{177} \mathrm{HfO}=0.283225$ and ${ }^{176} \mathrm{Lu} /{ }^{177} \mathrm{HfO}=0.038512$ (Vervoort and Blichert-Toft, 1999); CHUR - chondritic uniform reservoir, calculated using ${ }^{176} \mathrm{Hf} /{ }^{177} \mathrm{Hf}=0.282785$ and ${ }^{176} \mathrm{Lu} /{ }^{177} \mathrm{Hf}=0.0336$ (Bouvier et al., 2008). Black arrows show interpreted crustal evolution trajectories assuming present-day ${ }^{176} \mathrm{Lu} /{ }^{177} \mathrm{Hf}=0.0093$ (Vervoort and Patchett,1996; Vervoort et al., 1999; Bahlburg et al., 2011).

Figure. $10 \mathrm{EHf}_{(\mathrm{t})}$ values from the Fourth Lake and Comox Formations, the Banks Island Assemblage (Tochilin et al., 2014), SE Alaska (White et al., 2015), and Saint Elias Mountain region (Beranek et al., 2013a,b). Reference lines on the Hf plot are as follows: $\mathrm{DM}$-depleted mantle, calculated using ${ }^{176} \mathrm{Hf} /{ }^{177} \mathrm{HfO}=0.283225$ and ${ }^{176} \mathrm{Lu} /{ }^{177} \mathrm{HfO}=$ 0.038512 (Vervoort and Blichert-Toft,1999); CHUR — chondritic uniform reservoir, calculated using ${ }^{176} \mathrm{Hf} /{ }^{177} \mathrm{Hf}=0.282785$ and ${ }^{176} \mathrm{Lu} /{ }^{177} \mathrm{Hf}=0.0336$ (Bouvier et al., 2008). Black arrows show interpreted crustal evolution trajectories assuming present-day ${ }^{176} \mathrm{Lu} /{ }^{177} \mathrm{Hf}=0.0093$ (Vervoort and Patchett,1996; Vervoort et al., 1999; Bahlburg et al., 2011).

Figure 11. Plate-tectonic reconstruction of Paleozoic Wrangellia during the: (A-B) Late Devonian; (C) Late Devonian to Early Mississippian; (D) Early Mississippian; (E) Middle Mississippian; (F) Middle Mississippian to Middle Pennsylvanian; (G) Middle to Late Pennsylvanian; and (H) Early Permian. See text for additional information. 
Abbreviations: AX- the Alexander Terrane; AXa- Admiralty subterrane of Alexander Terrane; BGP- Barnard Glacier Pluton; CRP- Centennial Ridge Pluton; LGP-Logan Glacier porphyry; DGB-Donjek Glacier Batholith; SGP-Steel Glacier Pluton; FLFFourth Lake Formation; WR-Wrangellia; sWR- southern Wrangellia Arc; nWR-northern Wrangellia Arc. 
Figures

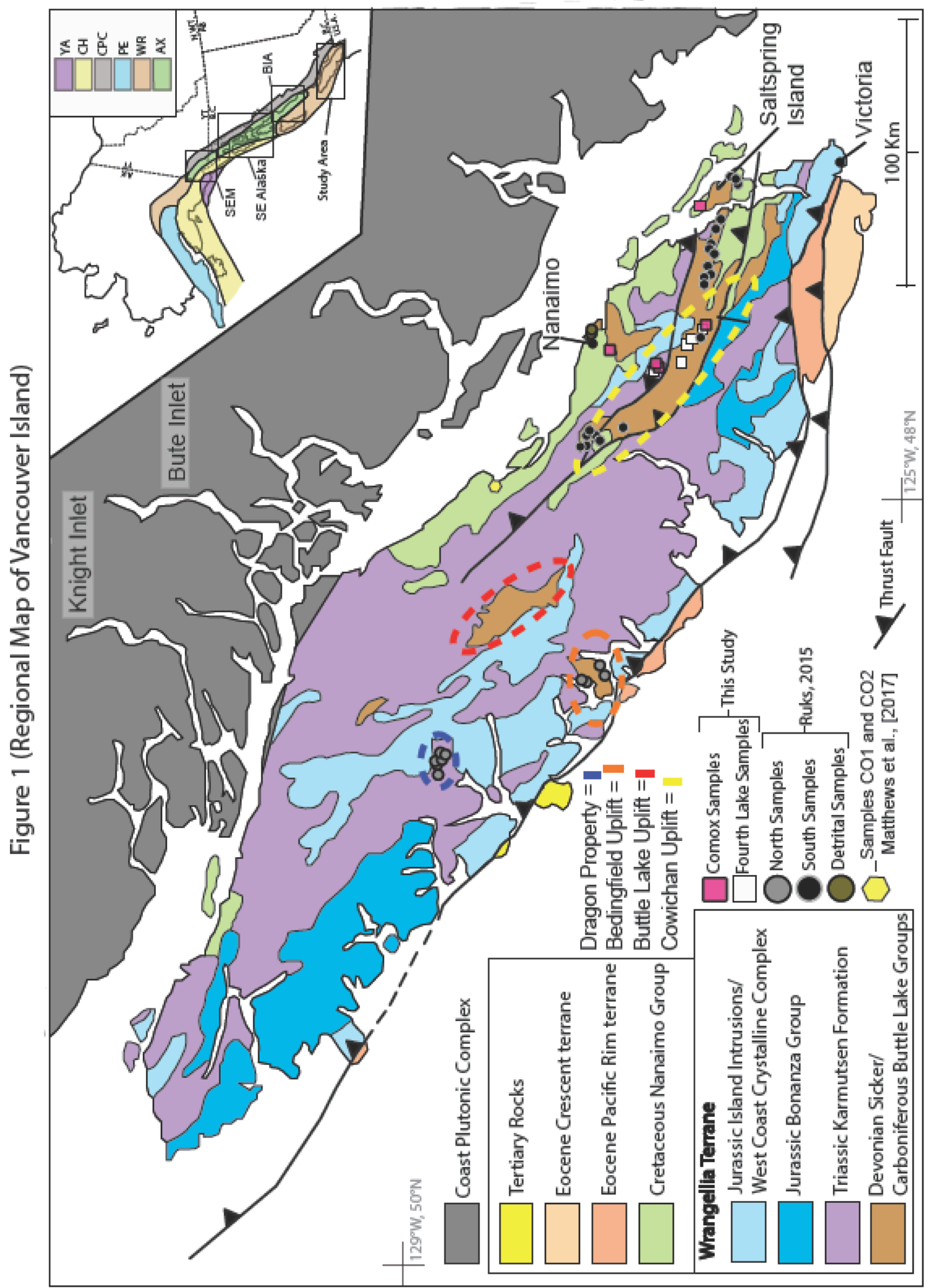


Figure 2 (General Stratigraphic Collumn of Vancouver Island)

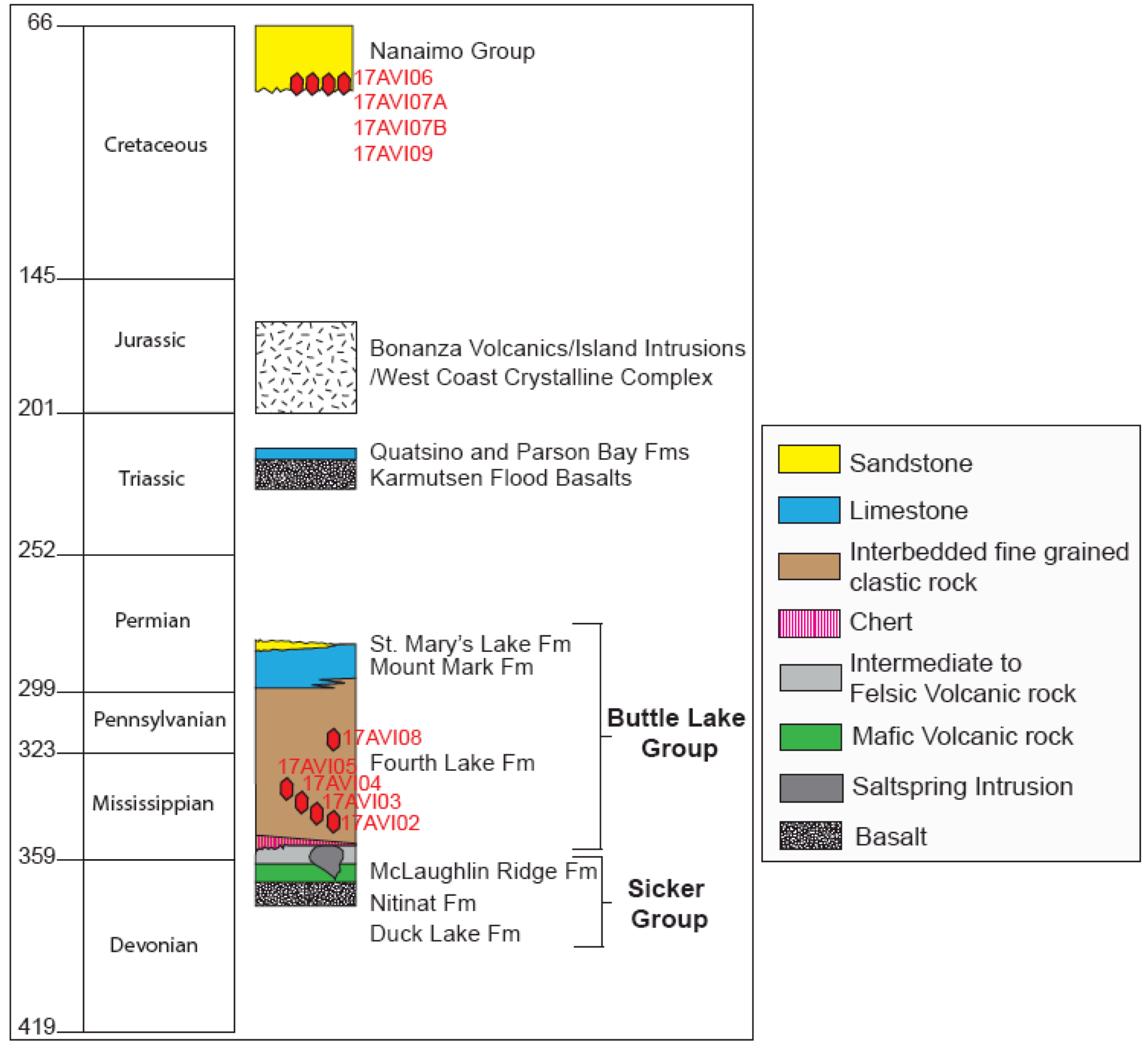


Figure 3 (Rock Pictures)

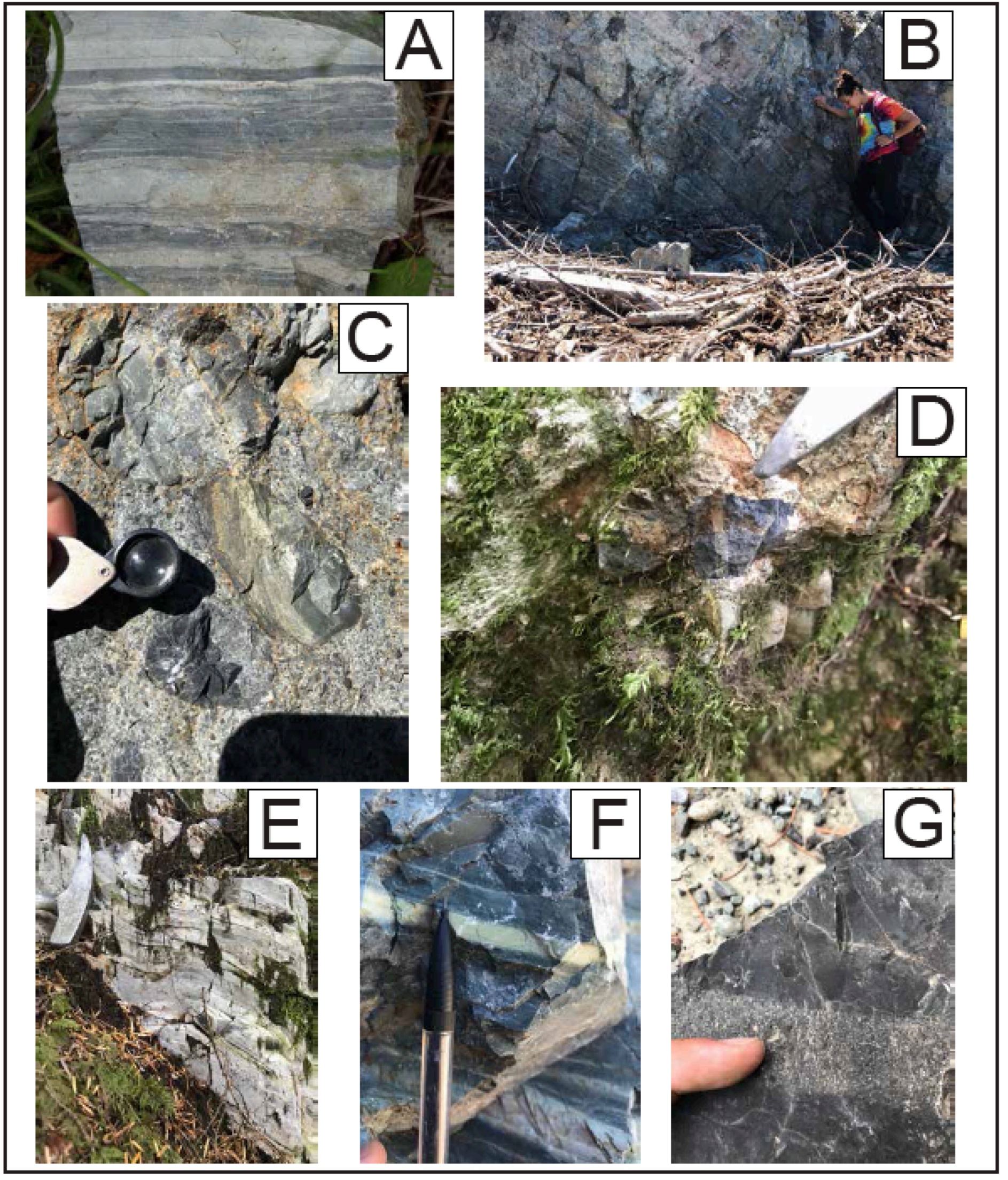




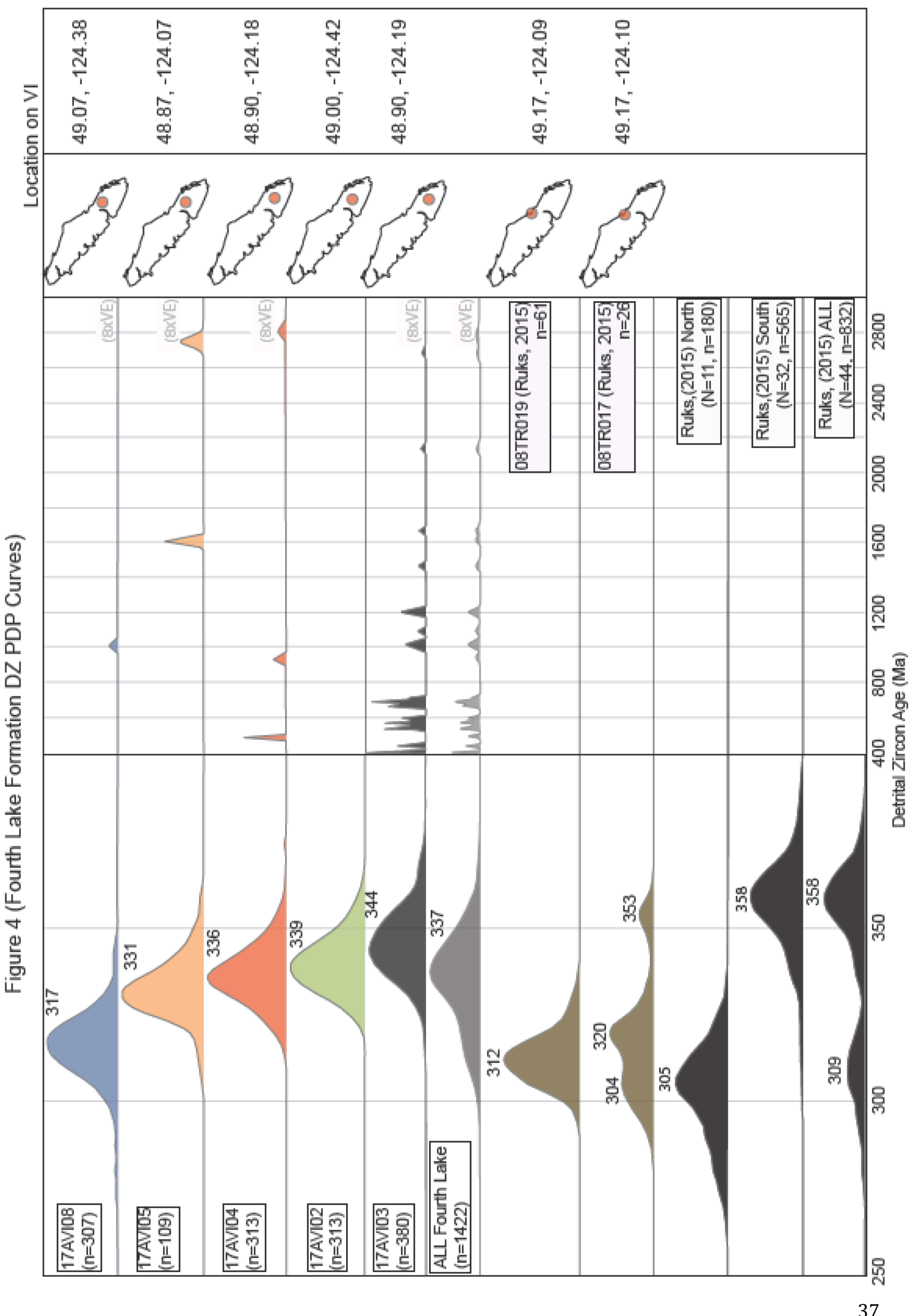




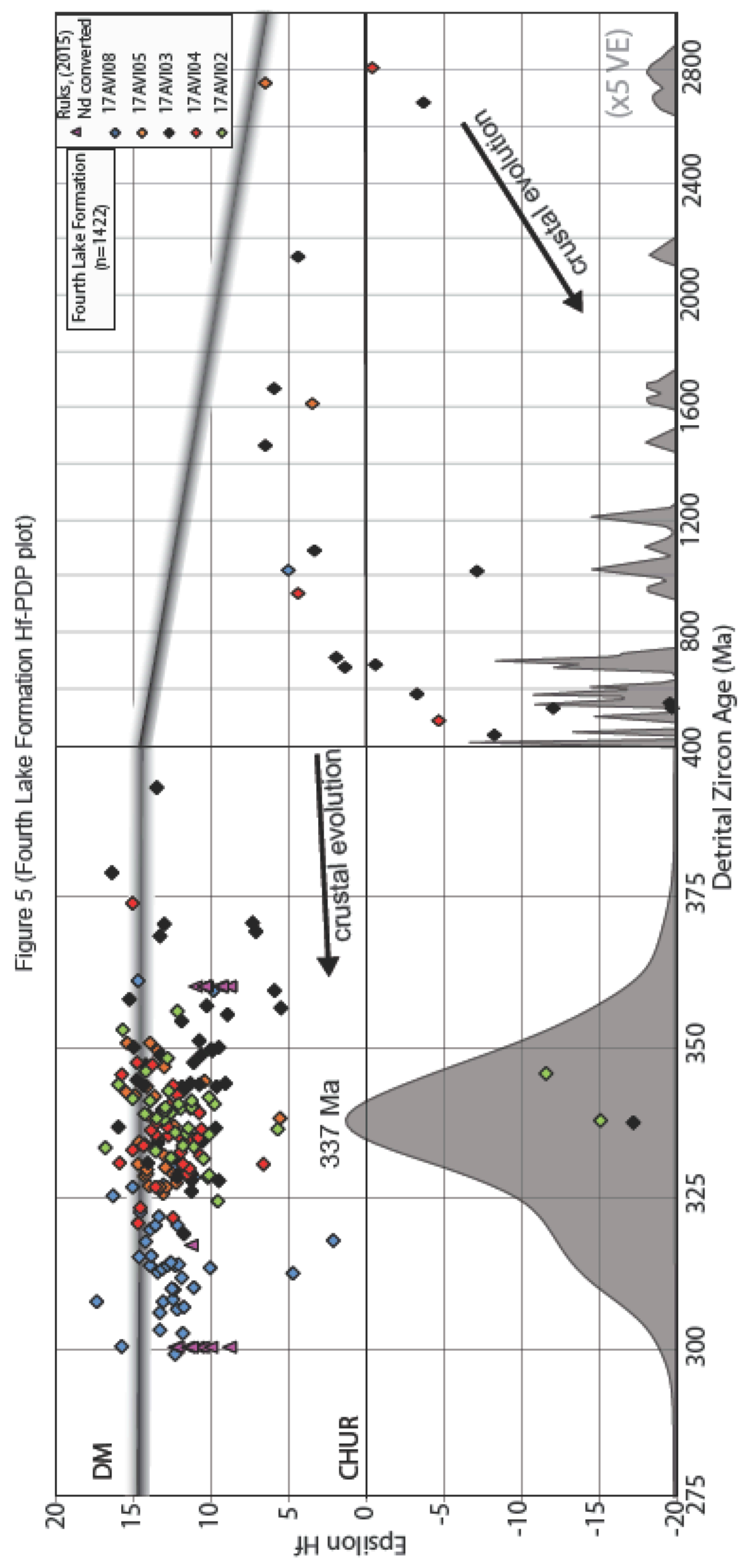


Figure 6 (Comox Formation DZ PDP Curves)

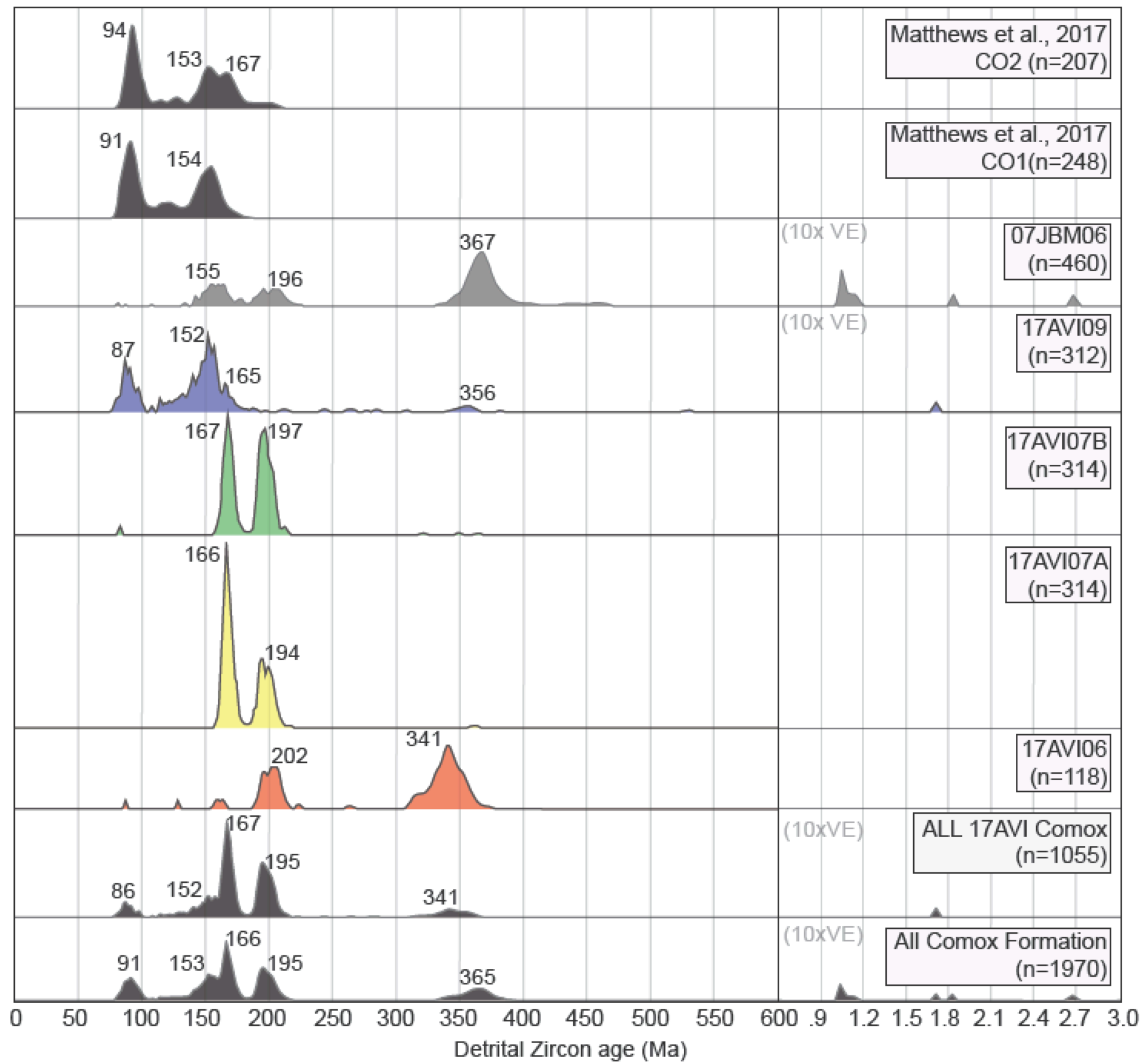


Figure 7 (Comox Formation and CMB Hf-PDP plot)

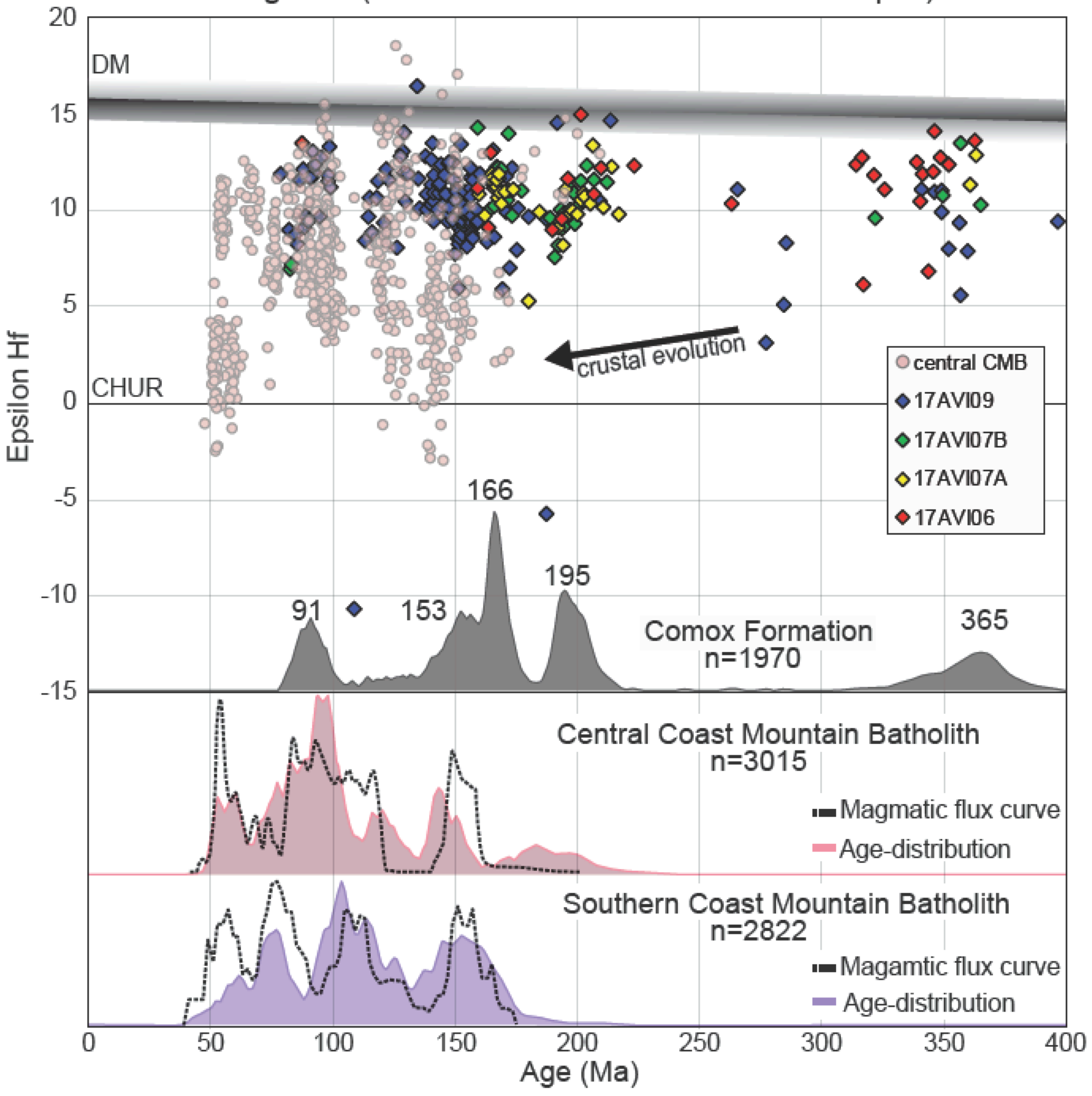


Figure 8 (Fourth Lake and Comox Formation Hf-PDP plot)

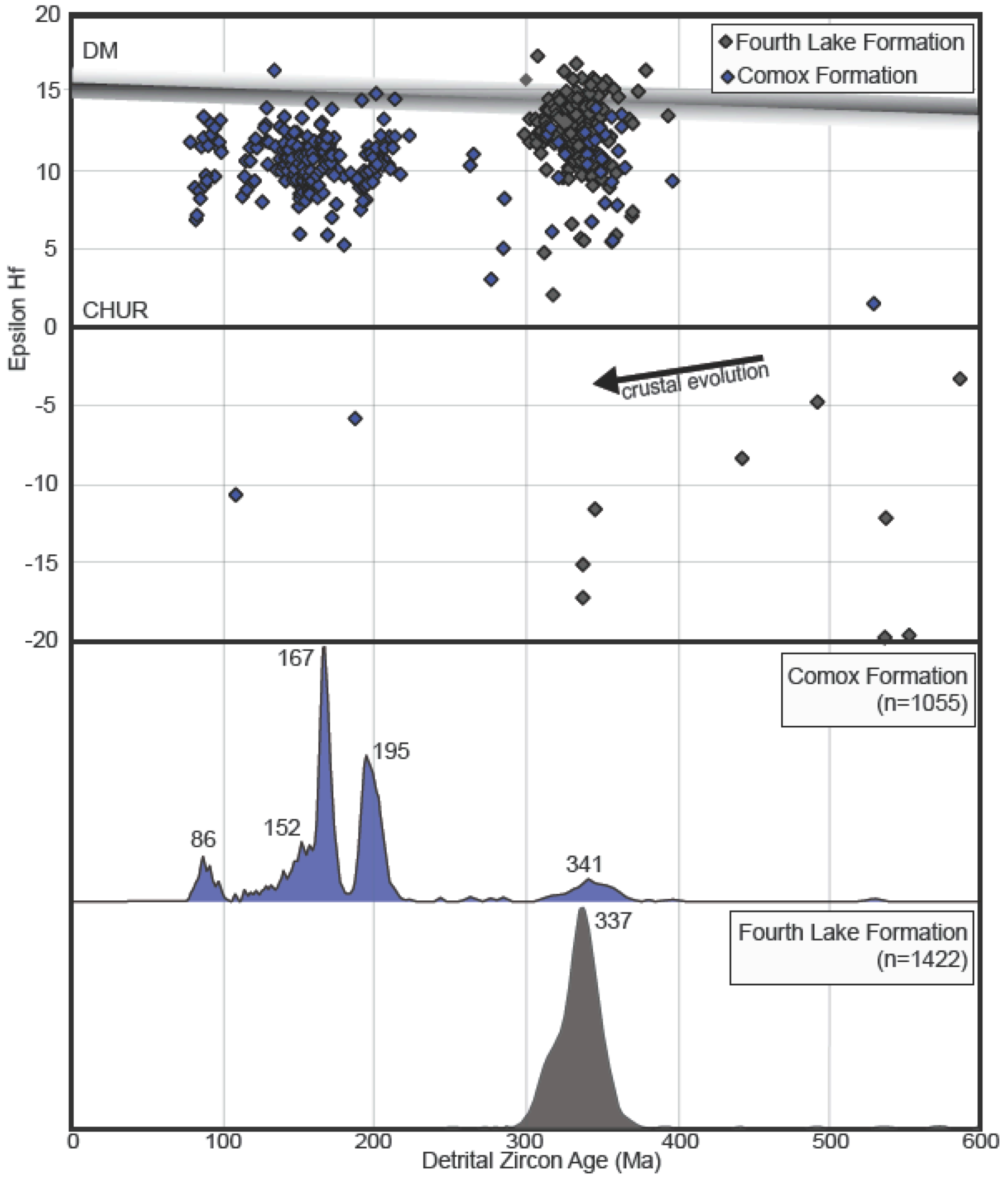




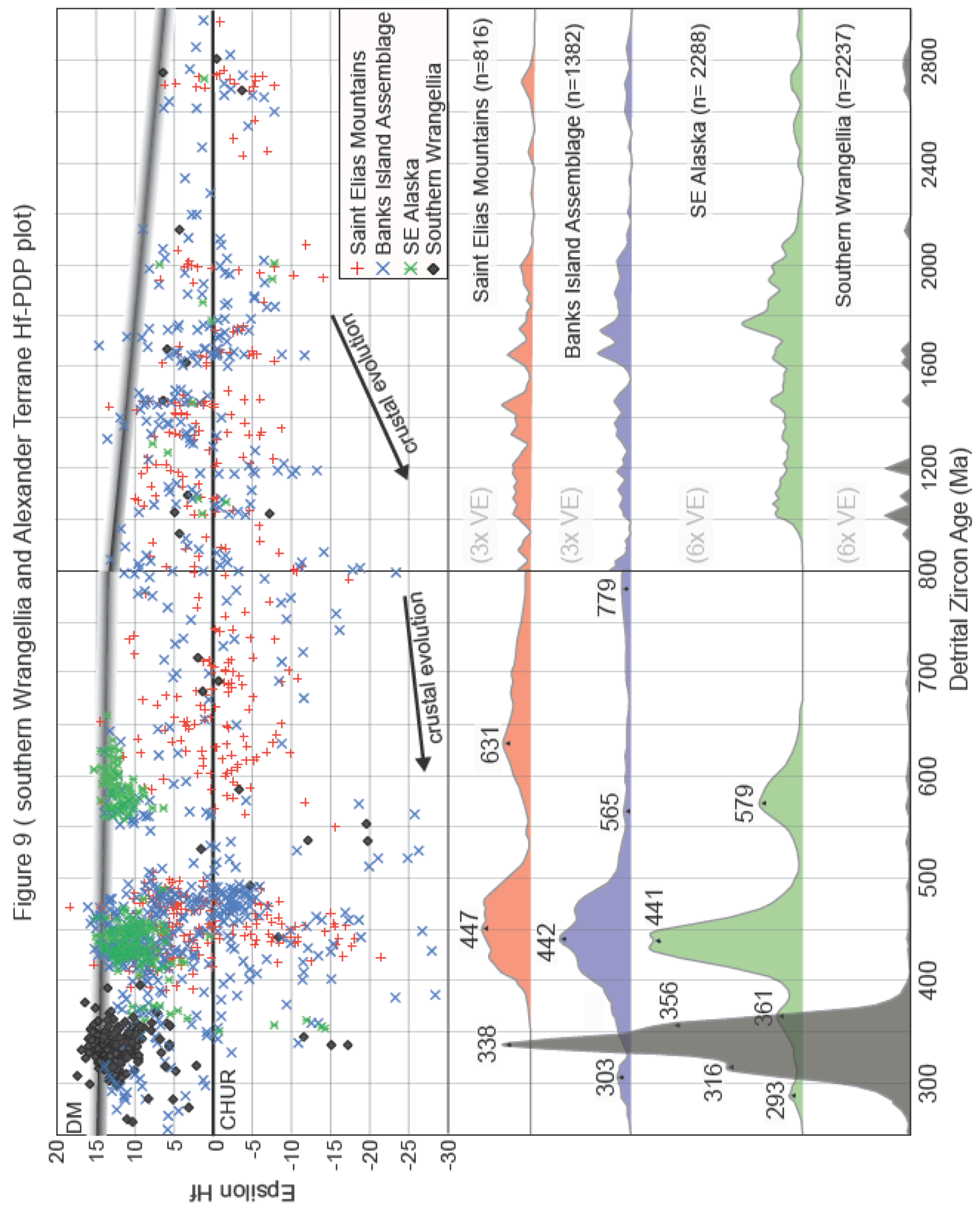




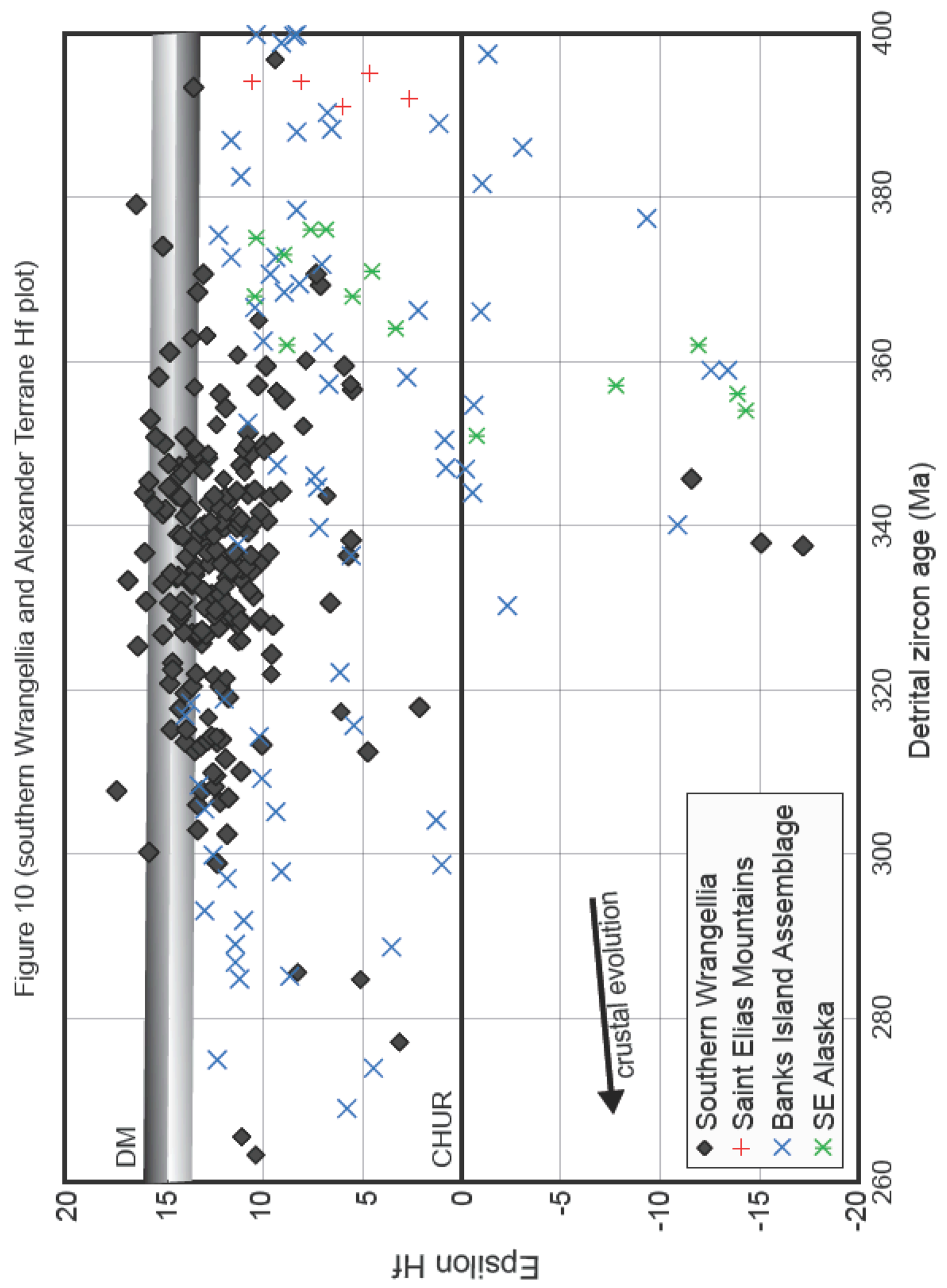



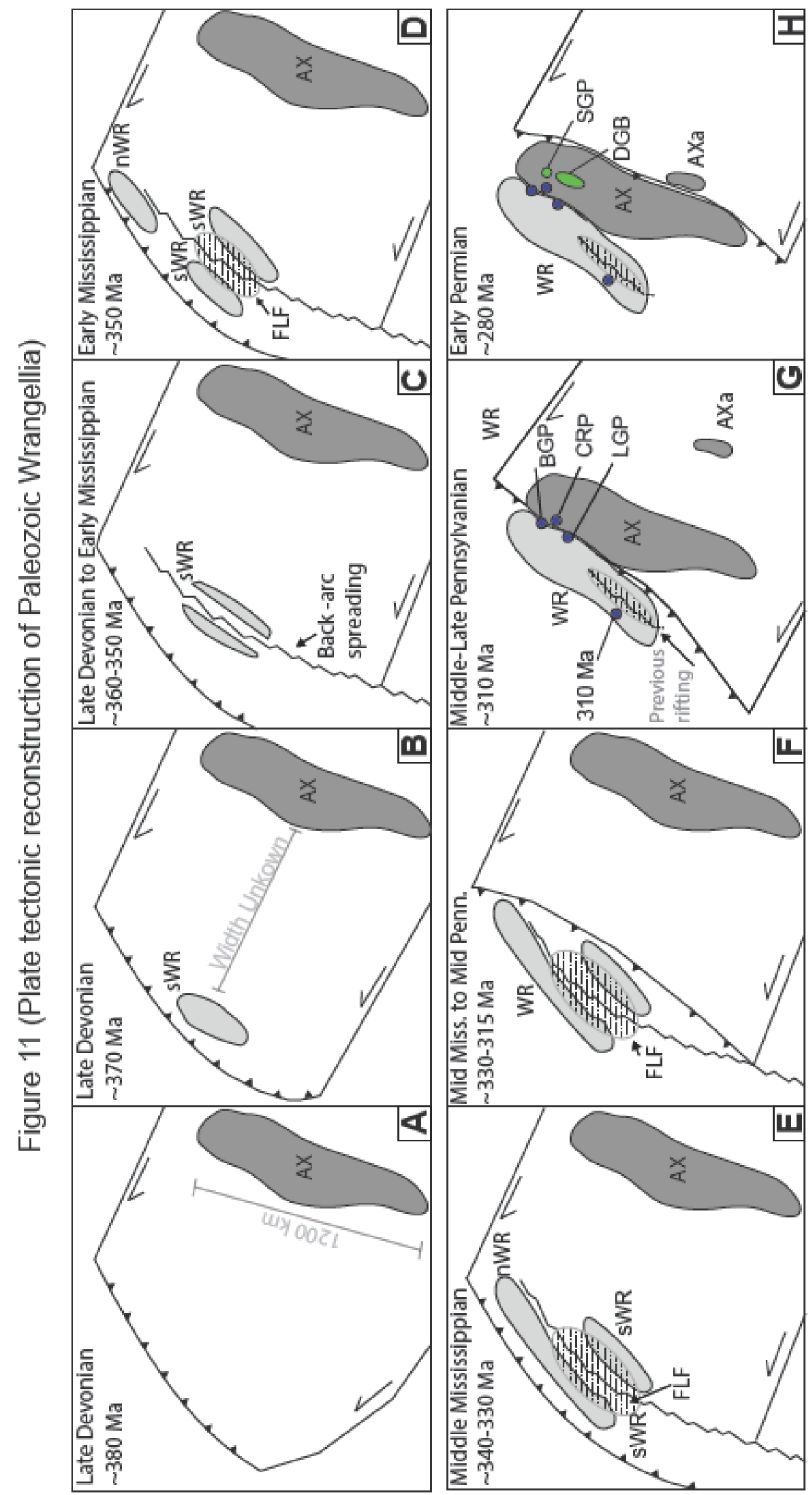


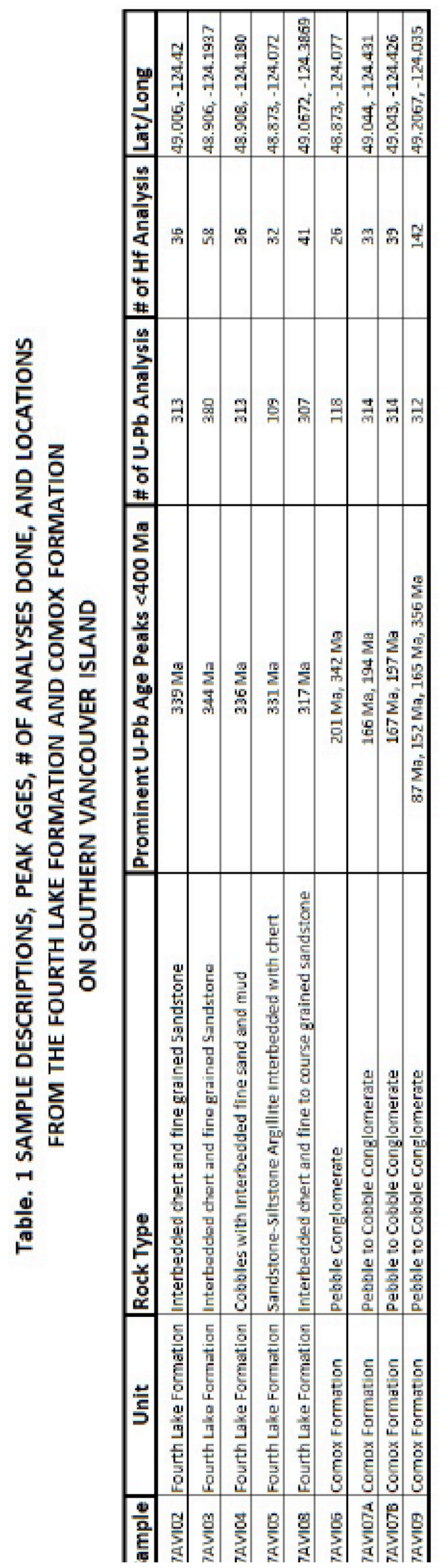




\section{References Cited}

Andrew, A., and Godwin, C.I., 1989, Lead- and Strontium-Isotope Geochemistry of Paleozoic Sicker Group and Jurassic Bonanza Group Volcanic Rocks and Island Intrusions, Vancouver Island, British Columbia: Canadian Journal of Earth Sciences, v. 26, p. 894-907.

Andrew, A., Armstrong, R.L., and Runkle, D., 1991, Neodymium-strontium-lead isotope study of Vancouver Island igneous rocks: Canadian Journal of Earth Sciences, v. 28, no. 11, p. 1744-1752, doi: https://doi.org/10.1139/e91-156.

Bahlburg, H., Vervoort, J.D., DuFrane, S.A., Carlotto, V., Reimann, C., and Cardenas, J., 2011, The U-Pb and Hf isotope evidence of detrital zircons of the Ordovician Ollantaytambo Formation, southern Peru, and the Ordovician provenance and paleogeography of southern Peru and northern Bolivia: Journal of South American Earth Sciences, v. 32, p. 196-209, doi:10.1016/j.jsames .2011 .07.002.

Bain, H., and Hubbard, S., 2016, Stratigraphic evolution of a long-lived submarine channel system in the late Cretaceous Nanaimo Group, British Columbia, Canada: Journal of Sedimentary Geology, v. 337, p. 113-132, doi:10.1016/j.sedgeo.2016.03.010.

Bazard, D.R., Butler, R.F., Gehrels, G.E., and Soja, C.M., 1995, Paleomagnetism of the Early Devonian Karheen Formation, southeast Alaska: Implications for Alexander terrane paleogeography: Geology, v. 23, p. 707-710, doi:10.1130/0091 7613(1995)023<0707:EDPDFT>2.3.CO;2.

Beranek, L.P., van Staal, C.R., Gordee, S.M., McClelland, W.C., Israel, S., and Mihalynuk, M.G., 2012, Tectonic significance of Upper Cambrian-Middle Ordovician mafic volcanic rocks on the Alexander terrane, Saint Elias Mountains, northwestern Canada: Journal of Geology, v. 120, p. 293-314, doi: 10.1130/L255.1. 
Beranek, L.P., van Staal, C.R., McClelland, W.C., Israel, S., and Mihalynuk, M.G., 2013a, Baltican crustal provenance for Cambrian-Ordovician sandstones of the Alexander terrane, North American Cordillera: Evidence from detrital zircon $\mathrm{U}-\mathrm{Pb}$ geochronology and Hf isotope geochemistry: Journal of the Geological Society of London, v. 170, p. 7-18, doi: 10.1144/jgs2012-028.

Beranek, L.P., van Staal, C.R., McClelland, W.C., Israel, S., and Mihalynuk, M.G., 2013b, Detrital zircon Hf isotopic compositions indicate a northern Caledonian connection for the Alexander terrane: Lithosphere, v. 5, p. 163-168, doi: 10.1130/L255.1.

Beranek, L., Van Staal, C., McClelland, W., Joyce, N., and Israel, S., 2014, Late Paleozoic assembly of the Alexander-Wrangellia-Peninsular composite terrane, Canadian and Alaskan Cordillera: Geological Society of America bulletin, v. 126, no. 11/12, p. 1531-1550, doi: 10.1130/31066.1.

Brandon, M. T., Orchard, M. J., Parrish, R. R., Sutherland Brown, A., and Yorath, C. J., 1986, Fossil ages and isotopic dates from the Paleozoic Sicker Group and associated intrusive rocks, Vancouver Island, British Columbia: Current Research Geological Survey of Canada, Paper 86-1A, p. 683-696.

Brown, E. H., 2012, Obducted nappe sequence in the San Juan Islands-northwest Cascades thrust system, Washington and British Columbia: Canadian Journal of Earth Sciences, v.49 (7), p. 796-817, doi: 10.1139/E2012-026.

Bouvier, A., Vervoort, J.D., and Patchett, J.D., 2008, The Lu-Hf and Sm-Nd isotopic composition of CHUR: Constraints from unequilibrated chondrites and implications for the bulk composition of terrestrial planets: Earth and Planetary Science Letters, v. 273, p. 48-57, doi: 10.1016/j.eps1.2008.06.010.

Butler, R.F., Gehrels, G.E., and Bazard, D.R., 1997, Paleomagnetism of Paleozoic strata of the Alexander terrane, southeastern Alaska: Geological Society of America 
Bulletin, v. 109 (10), p. 1372-1388, doi:10.1130/0016-7606 (1997)

109<1372:POPSOT>2.3.CO;2.

Butler, R.F., Gehrels, G.E., Hart, W., Davidson, C., and Crawford, M.L., 2006,

Paleomagnetism of Late Jurassic to mid-Cretaceous plutons near Prince Rupert, British Columbia, in Haggart, J.W., Enkin, R.J., and Monger, J.W.H., eds., Paleogeography of the North American Cordillera: Evidence For and Against Large-Scale Displacements: Geological Association of Canada Special Paper 46, p. 171-200.

Canil, D., Johnston, S.T., Larocque, J., Friedman, R., and Heaman, L.M., 2012, Age, construction, and exhumation of the midcrust of the Jurassic Bonanza arc, Vancouver Island, Canada: Lithosphere, v. 5 (1), p. 82-91, doi:10.1130/L225.1

Cecil, M.R., Gehrels, G.E., Ducea, M.N., Patchett, P.J., 2011, U-Pb-Hf characterization of the central Coast Mountains batholith: Implications for petrogenesis and crustal architecture: Lithosphere, v. 3, p. 247-260, doi: 10.1130/L134.1.

Cecil, M.R., Rusmore, M.E., Gehrels, G.E., Woodsworth, G.J., Stowell, H.H., Yokelson, I.N., Chisom, C., Trautman, M., and Homan, E., 2018, Along-strike variation in the magmatic tempo of the Coast Mountains batholith, British Columbia, and implications for processes controlling episodicity in arcs: Geochemistry, Geophysics, Geosystems, v. 19, 16 p., doi : 10.1029/2018GC007874.

Clift, P.D., Pavlis, T., DeBari, S.M., Draut, A.E., Rioux, M., and Kelemen, P.B., 2005, Subduction erosion of the Jurassic Talkeetna-Bonanza arc and the Mesozoic accretionary tectonics of western North America: Geology, v. 33, p. 881-884, doi:10.1130/G21822.1.

Colpron, M., Nelson, J.L., and Murphy, D.C., 2007, Northern Cordilleran terranes and their interactions through time: GSA Today, v. 17 (4/5), p. 4-10, doi: 10.1130/GSAT01704-5A.1. 
Colpron, M., and Nelson, J.L., 2009, A Palaeozoic Northwest Passage: incursion of Caledonian, Baltican and Siberian terranes into eastern Panthalassa, and the early evolution of the North American Cordillera: Geological Society of London, Special Publications 318, p. 273-307, doi: 10.1144/SP318.10.

Colpron, M., and Nelson, J.L., 2011, A Palaeozoic Northwest Passage and the Timanian, Caledonian and Uralian connections of some exotic terranes in the North American Cordillera, Chapter 31, in Spencer, A.M., Embry, A., Gautier, D., Stoupakova, A., and Sorensen, K., eds., Arctic Petroleum Geology: Geological Society of London, Memoirs 35, p. 463-484.

DeBari, S.M., Anderson, R.G., and Mortensen, J.K., 1999, Correlation among lower to upper crustal components in an island arc: the Jurassic Bonanza arc, Vancouver Island, Canada: Canadian Journal of Earth Science, v. 36, p. 1371-1413.

England, T. D. J., 1990, Late Cretaceous to Paleogene structural evolution of the Georgia basin, southwestern British Columbia, PhD thesis, Memorial Univ., Newfoundland.

Friedman, R.M., and Armstrong, R.L., 1995, Jurassic and Cretaceous geochronology of the southern Coast belt, British Columbia, $49^{\circ}$ to $51^{\circ} \mathrm{N}$, in Miller, D.M., and Busby, C., eds., Jurassic Magmatism and Tectonics of the North American Cordillera: Geological Society of America Special Paper 299, p. 95-139.

Friedman, R.M., and Nixon, G.T., 1995, U-Pb zircon dating of Jurassic porphyry $\mathrm{Cu}(-$ $\mathrm{Au}$ ) and associated acid sulphate systems, northern Vancouver Island, British Columbia, Geological Association of Canada - Mineralogical Association of Canada Annual Meeting, Victoria, B.C., pp. A-34.

Gardner, M.C., Bergman, S.C., Cushing, G.W., MacKevett, E.M., Plafker, G., Campbell, R.B., Dodds, C.J., McClelland, W.C., and Mueller, P.A., 1988, Pennsylvanian pluton stitching of Wrangellia and the Alexander Terrane, Wrangell Mountains, Alaska: Geology, v. 16 (11), p. 967-971. 
Gehrels, G.E., and Saleeby, J.B., 1987, Geologic framework, tectonic evolution, and displacement history of the Alexander terrane: Tectonics, v. 6, p. 151-174.

Gehrels, G., and Pecha, M., 2014, Detrital zircon U-Pb geochronology and Hf isotope geochemistry of Paleozoic and Triassic passive margin strata of western North America: Geosphere, v. 10 (1), p. 49-65, doi: 10.1130/GES00889.1.

Gehrels, G.E., Butler, R.F., and Bazard, D.R., 1996, Detrital zircon geochronology of the Alexander terrane, southeastern Alaska: Geological Society of America Bulletin, v. 108 , p. $722-734$.

Gehrels, G.E., Valencia, V.A., and Ruiz, J., 2008, Enhanced precision, accuracy, efficiency, and spatial resolution of U-Pb ages by laser ablation-multicollectorinductively coupled plasma mass spectrometry: Geochemistry Geophysics Geosystems, v. 9 (Q03017), 13 p.

Gehrels, G., Rusmore, M., Woodsworth, G., Crawford, M., Andronicos, C., Hollister, L., Patchett, J., Ducea, M., Butler, R., Klepeis, K., Davidson, C., Friedman, R., Haggart, J., Mahoney, B., Crawford, W., Pearson D., and Girardi, J., 2009, U-Th$\mathrm{Pb}$ geochronology of the Coast Mountains batholith in north-coastal British Columbia: Constraints on age and tectonic evolution: Geological Society of America Bulletin, v. 121, p. 1341-1361.

Girardi, J. D., Patchett, P. J., Ducea, M. N., Gehrels, G. E., Cecil, M. R., Rusmore, M. E., Woodsworth, G. J., et al. (2012). Elemental and isotopic evidence for granitoid genesis from deep-seated sources in the Coast Mountains batholith, British Columbia: Journal of Petrology, v. 53(7), p. 1505-1536, doi:

10.193/petrology/egs024.

Greene, A.R., Scoates, J.S., Weis, D., Katvala, C.E., Israel, S., Nixon, G.T., 2010, The architecture of oceanic plateaus revealed by the volcanic stratigraphy of the accreted Wrangellia oceanic plateau: Geosphere, v. 6 (1), p. 47-73. doi: 10.1130/GES00212.1. 
Haggart, J.W., Ward, P.D., and Orr, W. 2005, Turonian (Upper Cretaceous)

lithostratigraphy and biochronology, southern Gulf Islands, British Columbia, and northern San Juan Islands, Washington State: Canadian Journal of Earth Sciences, v. 42 (11), p. 2001-2020, doi:10.1139/e05-066.

Haggart, J. W., 1991, A synthesis of Cretaceous stratigraphy, Queen Charlotte Islands, British Columbia, in Woodsworth, G. J., ed., Evolution and hydrocarbon potential of the Queen Charlotte Basin, British Columbia: Geological Survey of Canada Paper 90-10, p. 253-277.

Haggart, J. W., and Carter, E. S., 1994, Biogeography of latest Jurassic and Cretaceous mollusc and radiolarian faunas of the Insular Belt, British Columbia, suggest minimal northward displacement: Geological Society of America Abstracts with Programs, v. 26(7), p. A148.

Isachsen, C.E., 1987, Geology, geochemistry, and cooling history of the West Coast Crystalline Complex and related rocks, Meares Island and vicinity, Vancouver Island, British Columbia: Canadian Journal of Earth Sciences, v. 24, p. 2047 2064, doi:10.1139/e87-194.

Israel, S., 2010, Geologic relationship of Wrangellia in Yukon: Implications for Insular terrane tectonics: Geological Society of America Abstracts with Programs, v. 42, no. 5 , p. 574 .

Israel, S., Beranek, L., Friedman, R.M., and Crowley, J.L., 2014, New ties between the Alexander terrane and Wrangellia and implications for North America Cordilleran evolution: Lithosphere, v. 6 (4), p. 270-276.

Johnstone, P.D., Mustard, P.S., and MacEachern, J.A., 2006, The basal unconformity of the Nanaimo Group, southwestern British Columbia: a Late Cretaceous stormswept rocky shoreline: Canadian Journal of Earth Sciences, v. 43, p. 1165-1181, doi:10.1139/E06-046. 
Juras, S., 1987, Geology of the Westmin Resources Myra Falls Mine-area, Vancouver Island, British Columbia: unpublished Ph.D. thesis, The University of British Columbia.

Katnick, D. C., and Mustard, P.S., 2003, Geology of Denman and Hornby islands, British Columbia: Implications for Nanaimo basin evolution and formal definition of the Geoffrey and Spray formations, Upper Cretaceous Nanaimo Group: Canadian Journal of Earth Science, v. 40 (3), p. 375-393, doi:10.1139/e03-005.

Katvala, E. C., and Henderson, C. M., 2002, Conodont sequence biostratigraphy and paleogeography of the Pennsylvanian-Permian Mount Mark and Fourth Lake formations, southern Vancouver Island, in Hills, L. V., Henderson, C. M., and Bamber, E. W., eds., Carboniferous and Permian of the World. Canadian Society of Petroleum Geologists, Memoir, p. 461-478.

Lassiter, J.C., 1995, Geochemical investigations of plume related lavas: Constraints on the structure of mantle plumes and the nature of plume/lithosphere interactions [Ph.D. thesis]: Berkeley, University of California, $231 \mathrm{p}$.

Mahoney, J. B., P. S. Mustard, J. W. Haggart, R. M. Friedman, C. M. Fanning, and V. J. McNicoll (1999), Archean zircons in Cretaceous strata of the western Canadian Cordillera: The "Baja B.C." hypothesis fails a "crucial test": Geology, v. 27(3), p. 195-198, doi:10.1130/0091-7613(1999)027<0195:AZICSO>2.3.CO;2.

Mahoney, J. B., Gordee, S. M., Haggart, J. W., Friedman, R. M., Diakow, L. J., and Woodsworth, G. J., 2009, Magmatic evolution of the eastern Coast Plutonic Complex, Bella Coola region, west-central British Columbia: Geologic Sociaty of America Bulletin, v. 121 (9/10), p. 1362-1380, doi:10.1130/B26325.1.

Massey, N. W. D., and Friday, S. J., 1987, Geology of the Cowichan Lake Area, Vancouver Island (92C/16): in Geological Fieldwork 1986. B.C. Ministry of Energy, Mines and Petroleum Resources Paper 1987-1, p. 223-229. 
Massey, N. W. D., and Friday, S. J., 1988, Geology of the Chemainus River-Duncan Area, Vancouver Island (92C/16; 92B/13): in Geological Fieldwork 1987. B.C. Ministry of Energy, Mines and Petroleum Resources Paper 1988-1, p. 81-91.

Massey, N. W. D., and Friday, S. J., 1989, Geology of the Alberni-Nanaimo Lakes Area, Vancouver Island (91F/1W, 92F/2E and part of 92F/7): in Geological Fieldwork 1987. B.C. Ministry of Energy, Mines and Petroleum Resources Paper 1989-1, p. $61-74$.

Massey, N. W. D., 1995a, Geology and mineral resources of the Alberni-Nanaimo Lakes sheet, Vancouver Island 92F/1W, 92F/2E, and part of 92F/7E. B.C. Ministry of Energy, Mines and Petroleum Resources. Paper 1992-2, 132 p.

Massey, N. W. D., 1995b, Geology and mineral resources of the Cowichan Lake sheet, Vancouver Island 92C/16. B.C. Ministry of Energy, Mines and Petroleum Resources. Paper 1992-3, 112 p.

Massey, N. W. D., 1995c, Geology and mineral resources of the Duncan sheet, Vancouver Island 92B/13. B.C. Ministry of Energy, Mines and Petroleum Resources. Paper 1992-4, 112 p.

Massey, N. W. D., MacIntyre, D. G., Desjardins, P. J., and Cooney, R. T., 2005a, Digital Geology Map of British Columbia: Tile NM9 Mid Coast, B.C. B.C. Ministry of Energy and Mines Geofile 2005-2.

Massey, N. W. D., Desjardins, P. J., and Cooney, R. T., 2005b, Digital map of British Columbia: Tile NM10 Southwest B.C: B.C. Ministry of Energy, Mines and Petroleum Resources, GeoFile 2005-3.

Matthews, W. A., Guest, B., Coutts, D., Bain, H., and Hubbard, S., 2017, Detrital zircons from the Nanaimo basin, Vancouver Island, British Columbia: An independent test of Late Cretaceous to Cenozoic northward translation: Tectonics, v. 36, p. 854 876, doi:10.1002/2017TC004531. 
Matysek, P.F., Gravel, J.L., Jackaman, W. and Feulgen, S., 1990, British Columbia Regional Geochemical Survey, Stream Sediment and Water Geochemical Data, Victoria/Cape Flattery - NTS 92BI 92C, Data Booklet: B.C. Minktry of Energy, Mines and Petroleum Resources, RGS 24.

Miller, E.L., Kuznetsov, N., Soboleva, A., Udoratina, O., Grove, M.J., and Gehrels, G.E., 2011, Baltica in the Cordillera?: Geology, v. 39, p. 791-794, doi:10.1130/G31910.1.

Muller, J.E., Wanless, R.K., and Loveridge, W.D., 1974, A Paleozoic zircon age of the Westcoast Crystalline Complex of Vancouver Island, British Columbia: Canadian Journal of Earth Sciences, v. 11, p. 1717-1722.

Muller, J.E., and Jeletzky, J.A., 1970, Geology of the Upper Cretaceous Nanaimo Group, Vancouver Island and Gulf Islands, British Columbia: Geological Survey of Canada, Paper 69-25,77 p.

Mustard, P.S., Mahoney, J.B., Haggart, J.W., Kimbrough, D.L., Grove, M., and Fanning, C.M., 2006, Utilizing detailed provenance analysis to constrain variations in basinwide depositional architecture: the Late Cretaceous Nanaimo basin, southwestern British Columbia, Canada: Geological Society of America Abstracts with Programs, 38: 503.

Mustard, P. S., 1994, The Upper Cretaceous Nanaimo Group, Georgia basin, in Geology and Geological Hazards of the Vancouver Region, Southwestern British Columbia: Geological Survey of Canada Bulletin, v. 481, edited by J. W. H. Monger, p. 27-95, Nat. Resour. Canada, British Columbia.

Mustard, P. S., Parrish, R. R., and McNicoll, V., 1995, Provenance of the Upper Cretaceous Nanaimo Group, British Columbia: Evidence from U-Pb analyses of detrital zircons: in Stratigraphic Development in Foreland Basins, SEPM Special Publication, v. 52, p. 112-127. 
Nelson, J.L., Colpron, M., and Israel, S., 2013, The Cordillera of British Columbia, Yukon, and Alaska: Tectonics and Metallogeny, in Colpron, M., Bissig, T., Rusk, B.G., and Thompson, J.F.H., eds., Tectonics, Metallogeny, and Discovery: The North American Cordillera and Similar Accretionary Settings: Society of Economic Geologists Special Publication 17, ch.3, p. 53-109.

Nixon, G.T., Hammack, J.L., Koyanagi, V.M., Payie, G.J., Massey, N.W.D., Hamilton, J.V., and Haggart, J.W., 1994, Preliminary Geology of the Quatsino - PortMcNeill Map Areas, Northern Vancouver Island (92L/12, 11): in Geological Fieldwork 1993, Grant, B. and Newell, J.M., Editors; B.C. Ministry of Energy, Mines and Petroleum Resources, Paper 1994-1, p. 63-85.

Nixon, G.T., and Orr, A.J., 2006, Recent revisions to the Early Mesozoic stratigraphy of northern Vancouver Island (NTS 102I; 092L) and metallogenic implications, British Columbia: in Geologic Fieldwork 2006, British Columbia Ministry of Energy, Mines and Petroleum Resources, Paper 2007-1 and Geoscience BC, Report 2007-1, p. 163-178.

Orchard, M. J., 1987, Conodonts from Western Canadian chert: Their nature, distribution and stratigraphic applicsation, in Austin, R. R., ed., Conodonts: Investigative techniques and Applications: Chichester, Ellis Horwood Ltd., for the British Columbia Micropaleontological Society, p. 94-119.

Parrish, R. R., and McNicoll, V. J., 1992, U-Pb age determinations from the southern Vancouver Island, area, British Columbia, Radiogenic Age and Isotope Studies: Report 5: Geological Survey of Canada, Paper 91-2, p. 79-86.

Paulson, B. D., 2010, Magmatic processes in the Jurassic Bonanza arc: insights from the Alberni region of Vancouver Island, Canada: unpublished Ph.D. thesis, Western Washington University Graduate School Collection, 111 p. 
Pearce, J. A., 1982, Trace element characteristics of lavas from destructive plate boundaries: in Thorpe, R. S., ed., Andesites: Orogenic Andesite and Related Rocks, J. Wiley and Sons, p. 525-548.

Plafker, G., Nokleberg, W. J., and Lull, J. S., 1989, Bedrock geology and tectonic evolution of the Wrangellia, Peninsular and Chugach terranes along the TransAlaska crustal transect in the Chugach Mountains and southern Copper River Basin, Alaska: Journal of Geophysical Research, v. 94, no. B4, p. 4255-4295.

Pullen, A., Ibanez-Mejia, M., Gehrels, G., Giesler, D., and Pecha, M., 2018, Optimization of a Laser Ablation-Single Collector-Inductively Coupled Plasma-Mass Spectrometer (Thermo Element 2) for accurate, precise, and efficient zircon U-ThPb geochronology: Geochemistry, Geophysics, Geosystems, v. 19, p. 3689-3705, doi:10.1029/2018GC007889.

Ruks, T.W., 2015, Stratigraphic and paleotectonic studies of Paleozoic Wrangellia and it's contained volcanogenic massive sulfide (VMS) occurrences, Vancouver Island, British Columbia, Canada: Dissertation, University of British Columbia, $360 \mathrm{p}$.

Samson, S. D., Patchett, P. J., Gehrels, G. E., and Anderson, R. G., 1990, Nd and Sr isotopic characterization of the Wrangellia Terrane and implications for crustal growth of the Canadian Cordillera: The Journal of Geology, v. 98, no. 5, p. 749762.

Sluggett, C. L., 2003, Uranium-lead age and geochemical constraints on Paleozoic and Early Mesozoic magmatism in Wrangellia Terrane, Saltspring Island, British Columbia: B.Sc. thesis, University of British Columbia, Vancouver, B.C., 56 p.

Soja, C.M., and Krutikov, L., 2008, Provenance, depositional setting, and tectonic implications of Silurian polymictic conglomerate in Alaska's Alexander terrane: in Blodgett, R.B., and Stanley, G.D., Jr., eds., The Terrane Puzzle: New Perspectives 
on Paleontology and Stratigraphy from the North American Cordillera: Geological Society of America Special Paper 442, p. 63-75, doi: 10 .1130/2008 .442 (04).

Soja, C.M., 1994, Significance of Silurian stromatolitesphinctozoan reefs: Geology, v. 22, p. 355-358, doi:10 .1130/0091 -7613 (1994)022<0355: SOSSSR>2 .3.CO;2.

Sutherland Brown, A., Yorath, C.J., Anderson, R.G., and Dom, K., 1986, Geological Maps of Southern Vancouver Island, LITHOPROBE 1; Geological Survey of Canada, Open File 1272, 10 sheets.

Tochilin, C.J., Gehrels, G.E., Nelson, J.L., and Mahoney, J.B., 2014, U-Pb and Hf isotope analysis of detrital zircons from the Banks Island assemblage (coastal British Columbia) and southern Alexander terrane (southeast Alaska): Lithosphere, v. 6, p. 200-215, doi:10.1130/L338.1.

van der Heyden, P., 1989, U-Pb and K-Ar Geochronometry of the Coast Plutonic Complex, $53^{\circ} \mathrm{N}$ to $54^{\circ} \mathrm{N}$, British Columbia, and Implications for the InsularIntermontane Superterrane Boundary: Dissertation, University of British Columbia, Vancouver, B.C., 392 p.

van der Heyden, P., 1992, A Middle Jurassic to early Tertiary Andean-Sierran arc model for the Coast belt of British Columbia: Tectonics, v. 11, p. 82-97, doi: 10.1029/91TC02183.

Vervoort, J.D., and Patchett, P.J., 1996, Behavior of hafnium and neodymium isotopes in the crust: Constraints from crustally derived granites: Geochimica et Cosmochimica Acta, v. 60 (19), p. 3717-3733.

Vervoort, J.D., and Blichert-Toft, J., 1999, Evolution of the depleted mantle: Hf isotope evidence from juvenile rocks through time: Geochimica et Cosmochimica Acta, v. 63, p. 533-556.

Vervoort, J.D., Patchett, P.J., Blichert-Toft, J., and Albarede, F., 1999, Relationships between Lu-Hf and Sm-Nd isotopic systems in the global sedimentary system: 
Earth and Planetary Science Letters, v. 168, p. 79-99, doi:10.1016 /S0012 -821X (99)00047-3.

Walker, J.D., Geissman, J.W., Bowring, S.A., and Babcock, L.E., compilers, 2012, Geologic Time Scale v. 4.0: Boulder, Colorado, Geological Society of America, doi: 10.1130/2012 .CTS004R3C.

Webster, G. D., Haggart, J.W., Saxifrage, C., Saxifrage, B., Gronau, C., Douglas, A., 2009, Globally significant Early Permian crinoids from the Mount Mark Formation in Strathcona Provincial Park, Vancouver Island, British Columbia preliminary analysis of a disappearing fauna: Canadian Journal of Earth Sciences, v. 46 (9), p. 663-674, doi:10.1139/E09-039.

Wetmore, P.H., and Ducea, M.N., 2011, Geochemical evidence of a near-surface history for source rocks of the central Coast Mountains Batholith, British Columbia: International Geology Review, v. 53 (2), p. 230 260, doi: 10.1080/00206810903028219.

White, C., Gehrels, G.E., Pecha, M., Giesler, D., Yokelson, I., McClelland, W.C., and Butler, R.F., 2016, U-Pb and Hf isotope analysis of detrital zircons from Paleozoic strata of the southern Alexander terrane (southeast Alaska): Lithosphere, v. 8 (1), p. 83-96, doi:10.1130/L475.1.

Yorath, C.J., Sutherland Brown, A., and Massey, N.W.D., 1999, LITHOPROBE, southern Vancouver Island, British Columbia: Geological Survey of Canada, Bulletin 498, 145 p. 